\title{
Current Status of Health and Safety Issues of Sodium/Metal Chloride (Zebra) Batteries
}

David Trickett

National Renewable Energy Laboratory

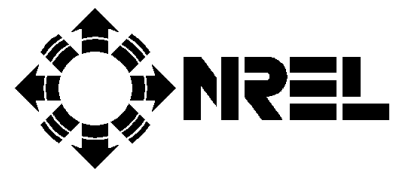

National Renewable Energy Laboratory 1617 Cole Boulevard Golden, Colorado 80401-3393

A national laboratory of the U.S. Department of Energy Managed by Midwest Research Institute for the U.S. Department of Energy under contract No. DE-AC36-83CH10093 


\section{Current Status of Health and Safety Issues of Sodium/Metal Chloride (Zebra) Batteries}

David Trickett

National Renewable Energy Laboratory

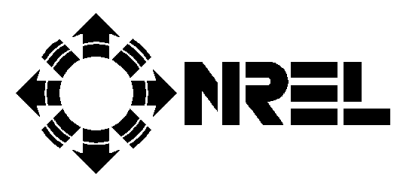

National Renewable Energy Laboratory 1617 Cole Boulevard Golden, Colorado 80401-3393

A national laboratory of the U.S. Department of Energy Managed by Midwest Research Institute for the U.S. Department of Energy under contract No. DE-AC36-83CH10093

Prepared under Task No. WW171000

November 1998 


\section{NOTICE}

This report was prepared as an account of work sponsored by an agency of the United States government. Neither the United States government nor any agency thereof, nor any of their employees, makes any warranty, express or implied, or assumes any legal liability or responsibility for the accuracy, completeness, or usefulness of any information, apparatus, product, or process disclosed, or represents that its use would not infringe privately owned rights. Reference herein to any specific commercial product, process, or service by trade name, trademark, manufacturer, or otherwise does not necessarily constitute or imply its endorsement, recommendation, or favoring by the United States government or any agency thereof. The views and opinions of authors expressed herein do not necessarily state or reflect those of the United States government or any agency thereof.

Available to DOE and DOE contractors from:

Office of Scientific and Technical Information (OSTI)

P.O. Box 62

Oak Ridge, TN 37831

Prices available by calling 423-576-8401

Available to the public from:

National Technical Information Service (NTIS)

U.S. Department of Commerce

5285 Port Royal Road

Springfield, VA 22161

703-605-6000 or 800-553-6847

or

DOE Information Bridge

http://www.doe.gov/bridge/home.html 


\section{Preface}

Sodium/metal chloride (Zebra) batteries are a mid- to long-term candidate technology for electric vehicle (EV) propulsion. Understanding environmental, health, and safety issues associated with sodium/metal chloride batteries is an important step toward their commercialization. This report examines the EH\&S issues associated with the use of sodium/metal chloride batteries as the energy source in EVs.

The Analytic Studies Division (ASD) prepared this report for AEG Zebra Marketing, the primary developer of Zebra batteries. The objectives of this report are to perform secondary research on EH\&S issues associated with Zebra batteries for electric vehicles, and to report the results of that research in an EH\&S assessment.

\section{Acknowledgements}

I am indebted to the many people who helped obtain information for this report. These include:

Jeff Braithwaite (SNL), Jim DeGruson (Eagel-Picher Industries), Heinz Hammerling (Thomson Components and Tubes), Gary Henriksen (ANL), Michael F. Mangan (MANGAN Technical Services), Russell Moy (Ford Motor Company), and Ahmad Pesaran (NREL) for providing in-depth peer review comments, criticisms, and recommendations.

Jim Sudworth and Roger Tilley, of Beta Research and Development, Ltd., Cord-Henrich. Dustmann and Harold Böhm, of AEG Zebra, and Malcom Shemmans, of BET Services, for patiently and candidly answering the numerous (and often esoteric) technical questions I directed toward them.

Don Vissers and Laszlo Redey, of ANL, for providing additional technical expertise and peer review comments, as well as contextual information about the development of this technology and its sodium/sulfur antecedent.

And Ron Iori (Ford Motor Company), for providing a succinct description of the Q1 certification program.

Special acknowledgements are due Andy Altemos (HMT and Associates) for providing key information and recommended wording used in the shipping section, Jim Leyshon (NREL) for providing the pictorial representation of the Zebra cell used in the report, and Laura Vimmerstedt (NREL) for significant bibliographic research and contract management support.

Approved for the

NATIONAL RENEWABLE ENERGY LABORATORY
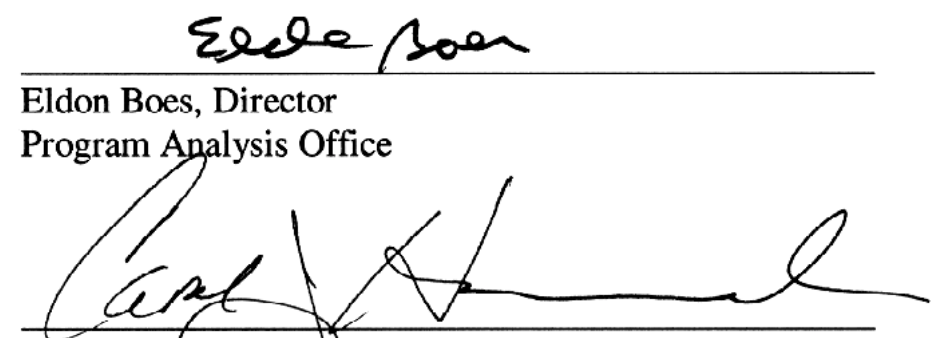

Carol J. Hammel, Project Manager

EV Battery EH\&S A ssessments

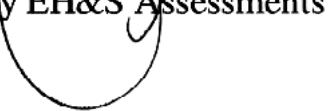




\section{Executive Summary}

This report addresses environmental, health, and safety (EH\&S) issues associated with sodium/ metal chloride batteries, in general, with specific references to unit, developed or being developed by AEG Zebra Marketing.

Sodium/metal chloride cells, referred to as Zebra cells or the Zebra system, operate at relatively high temperatures, use a negative electrode composed of liquid sodium, and use a ceramic electrolyte to separate this electrode from the positive electrode. In these respects, they are similar to sodium/sulfur cells. However, sodium/metal chloride cells also include a secondary electrolyte of molten sodium tetrachloroaluminate $\left(\mathrm{NaAlCl}_{4}\right)$ in the positive electrode section and an insoluble transition metal chloride $\left(\mathrm{FeCl}_{2}\right.$ or $\left.\mathrm{NiCl}_{2}\right)$ or a mix of such chlorides, as the positive electrode.

The positive electrode is fabricated in the discharged state from a mixture of common salt, nickel, iron, and aluminum. The initial charge oxidizes these metals and decomposes the salt to sodium and chloride ions, with the chloride ions combining with the oxidized metals. Discharge results in the reverse reaction. The positive electrode section of the cell also contains the liquid electrolyte, sodium tetrachloroaluminate, which serves to conduct sodium ions between this electrode and the ceramic electrolyte tube.

The electrodes are separated by an impermeable, white ceramic produced from oxides and hydroxides of aluminum, sodium, and lithium, and known as sodium beta alumina ( $\beta$-alumina or $\beta-\mathrm{Al}_{2} \mathrm{O}_{3}$ ). This tube-like structure serves as a physical separator, preventing direct chemical reactions between the electrode constituents, and as a conductor of sodium ions between the electrodes.

The negative electrode consists of sodium metal in liquid phase. It is contained between the cell casing and exterior of the $\beta$-alumina tube. Because the sodium constituting the negative electrode is obtained during the initial charge, metallic sodium need not be handled or used during the manufacture of Zebra cells. This aspect of fabrication has significant EH\&S implications for the manufacturing phase of the cells' life cycle, as well as for cell recycling or dismantlement.

The contents of Zebra cells are contained within a hermetically sealed steel case. Enclosure within the case makes exposure to nickel, nickel compounds, or sodium unlikely during normal operation. The cells do not vent gases or other substances during normal operation, and do not contain materials characterized by having high vapor pressures at the temperature ranges associated with such operation.

Zebra cells are housed within a temperature-controlled, double-walled, sealed, vacuum-insulated battery case. This battery case or enclosure is intended to both protect the outside environment from the effects of mishaps within, and to protect internal battery components from hazards outside. ${ }^{1}$ Accidents resulting in the penetration of the battery case can be expected to compromise its insulating and containment functions, and if severe enough, to rupture the cells contained inside.

\footnotetext{
${ }^{1}$ Dustmann and Tilley (1996), p. 114.
} 
This report finds the following to apply to Zebra technology in general:

1. Cell failures have been shown to have non-catastrophic results.

2. Cell failure chain reactions are difficult to sustain, but if sustained might, under some conditions - and depending upon EV design—result in significant safety impacts.

3. When subjected to extreme external influences simulating vehicle accidents, batteries do not appear likely to add additional significant hazards to occupants or emergency response personnel. (See recommendations.)

4. Cell failure shunts (looping elements) are unnecessary and therefore do not present additional hazards from failure.

5. Cells have a relatively wide operating temperature range.

6. Batteries can operate at a wide range of ambient temperatures because of their thermal management systems and insulated cases.

7. Cells are tolerant of freeze/thaw cycling.

8. Cell constituents have low vapor pressures at operating temperatures and most temperatures to which they are likely to be exposed.

9. When cells are exposed to high enough temperatures to compromise their containment function, the EH\&S hazards imposed from the resulting failure appear to be small. (See recommendation 2.)

10. Sources of chronic corrosion are absent.

11. Cells may be fabricated without handling or using metallic sodium.

12. Cells can be designed to fail safely when overcharged.

13. Cells fail safely when overdischarged.

14. Safe recycling of the batteries and cells appears to be possible.

15. Batteries can be safely and legally shipped in the cold state.

The Zebra system appears, from the available information, to be relatively safe with respect to severe influences of the kind normally associated with vehicle collisions or accidents. While it must be emphasized that this evaluation does not include, and has not been made with a rigorous quantitative comparison with other battery technologies, or other EV energy sources, it does derive from a review of the literature (much of which has been written by AEG Zebra affiliates) and testing up to date, and appears to be shared by others who are knowledgeable about it and related technologies. However, a more concrete appraisal could be made if certain questions, referenced in the following recommendations, were addressed.

1. Zebra developers should regularly report on the experience of the pilot program, and compile information on EH\&S incidents experienced during its course to: (1) identify any hazards that may as yet be unidentified, and provide information on how to mitigate or remove them; and (2) provide information from which to maintain up-to-date assessments of the system's safety.

2. Zebra developers should determine the likely aluminum hydroxide and hydrogen chloride exposure pathways for occupants or emergency response personnel, as a result of cell rupture, per the recommendation of the Motor Industries Research Association (MIRA).

3. Although it seems apparent that under some circumstances, significant hot spots could develop in the battery interior, which coupled with a compromised insulating ability, might reduce the battery system's ability to prevent significant heating of corresponding portions of the battery's exterior, it is not clear what effect this would have on the rest of the EV or the safety of the occupants. These questions should be addressed and answered, perhaps with the collaboration of EV manufacturers. 
4. AEG Zebra stresses that a breached cell is very unlikely to release sodium, since any trauma capable of breaching the cell will almost certainly simultaneously fracture the ceramic electrolyte, binding all available sodium into sodium chloride. ${ }^{2}$ It also stress that to its knowledge, free sodium has never been released in any of the tests conducted by MIRA. ${ }^{3}$ Given this background, it seems that the release of metallic sodium from Zebra cells in an operational battery is unlikely; however, the effects of such an event still remain unclear. Investigation should be undertaken to determine: (1) if there are (relevant) circumstances under which an operating Zebra cell would, in fact, release sodium, and (2) what effects sodium released from a cell or set of cells would have in an operating battery-perhaps via a simulation akin to that conducted for sodium tetrachloroaluminate.

5. The safety implications of using aqueous fire extinguishing agents on damaged Zebra batteries, although addressed in the MIRA test referenced, have not been investigated to the degree concerns about them warrant. The MIRA test is very encouraging, but seems to have been rather limited in scope since it did not make clear how many cells were actually ruptured and their contents available for reaction with water. Moreover, it is not clear that the extinguishing media should have been applied after the specified waiting periods had elapsed. It is recommended that the test be repeated, with fire extinguishing media applied while combustion was still visible, and under conditions in which the battery was more heavily damaged.

6. The failure mode of cells in batteries subjected to water immersion is not specified in the literature reviewed, although the reference to the immersion test indicates that none of the cells opened. It would be instructive to know the exact nature of this mechanism since seal failure or jacket breach could result in the exposure of water to sodium, while a ceramic electrolyte fracture would presumably result only in the failure of the cell in the conducting mode.

7. Independent testing by NREL, ANL or another DOE laboratory of the new "mixed cathode" batteries is recommended.

This review of the open literature, and discussions with authoritative sources, did not reveal any EH\&S issues that could seriously impair the use of this technology in electric vehicles. However, it is recommended by the author that these conclusions be further substantiated by testing at NREL, ANL, SNL, or another government laboratory or testing facility.

\footnotetext{
${ }^{2}$ See, for example, van Zyl and Dustmann (1995), p. 62.

${ }^{3}$ Memorandum from Jim Sudworth (Beta Research and Development, Ltd.) 9/29/98; Memorandum from

Dr. H. Böhm (AEG ZEBRA Battery Marketing) 10/7/98.
} 


\section{Table of Contents}

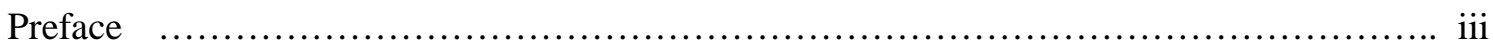

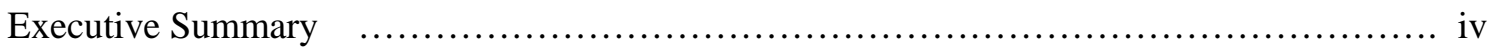

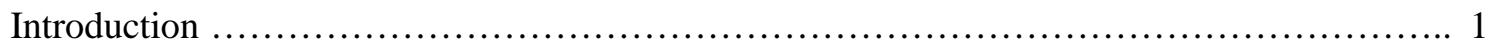

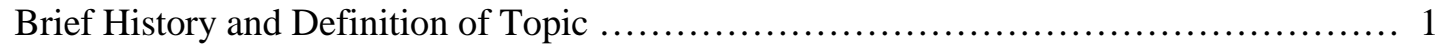

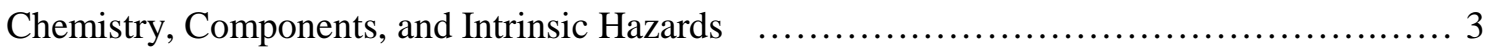

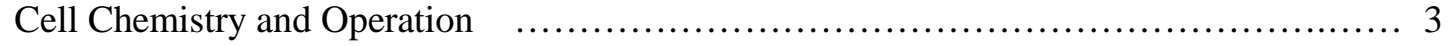

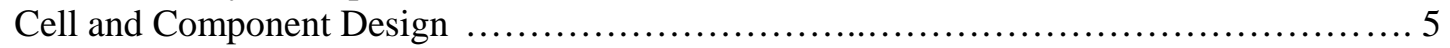

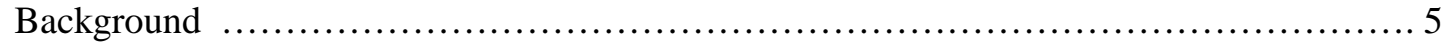

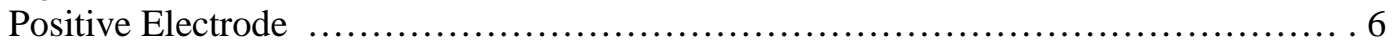

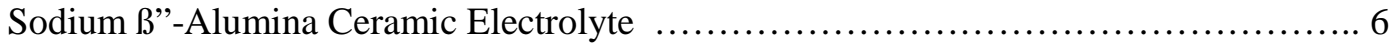

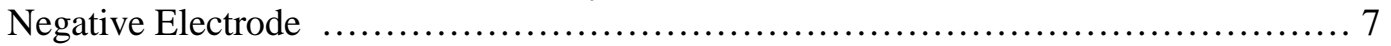

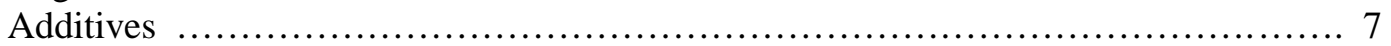

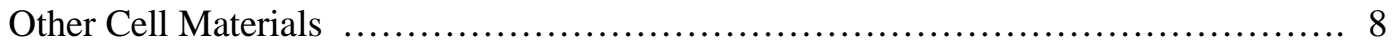

Intrinsic Material Hazards, Independent of Cell Design and Operation $\quad \ldots \ldots \ldots \ldots \ldots \ldots \ldots$

Background .................................................................... 8

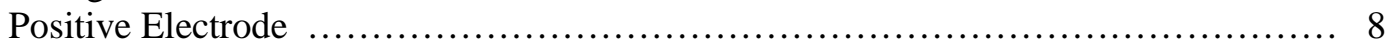

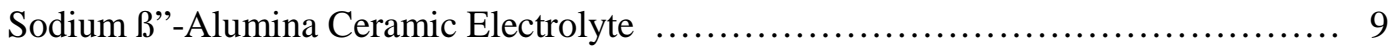

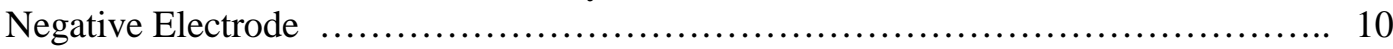

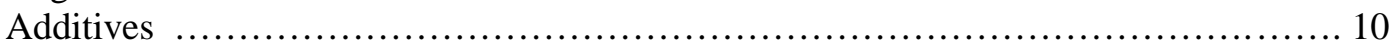

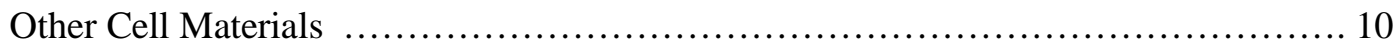

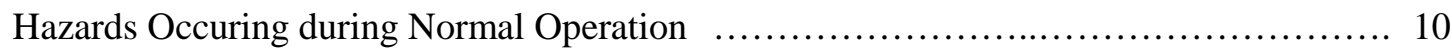

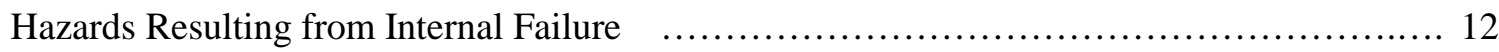

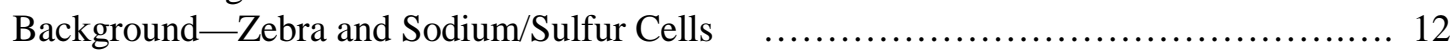

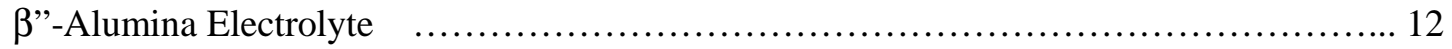

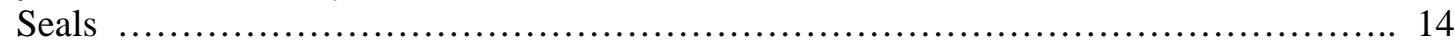

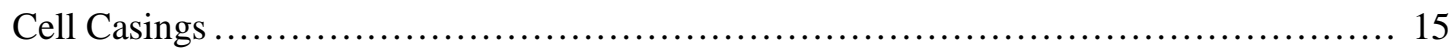

Effect of Individual Cell Failures on Other Cells ................................... 15

Cell Failure Shunts (Looping Elements) between Cells .............................. 15

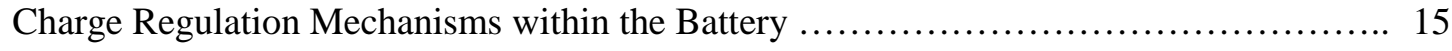

Insulation and Thermal Management System ..................................... 16

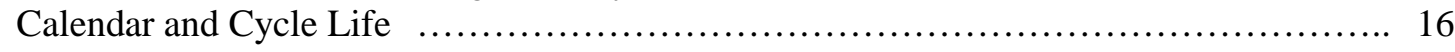

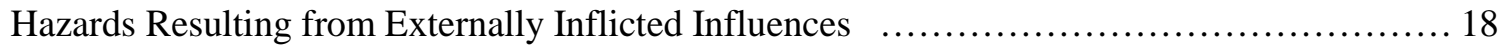

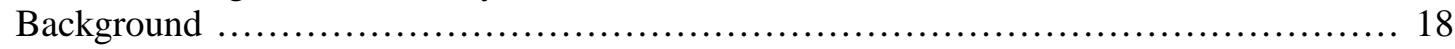

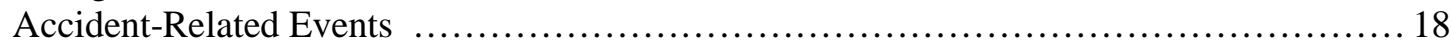

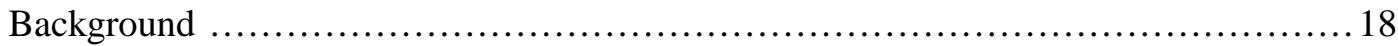

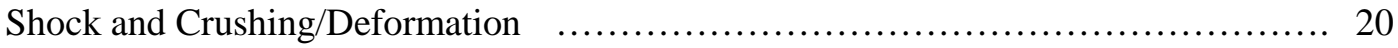

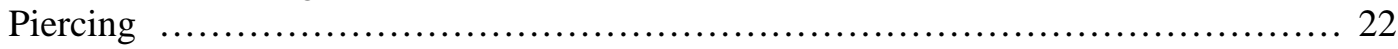

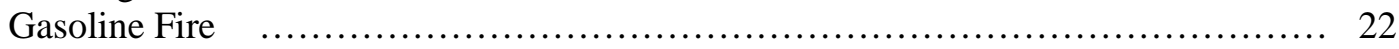

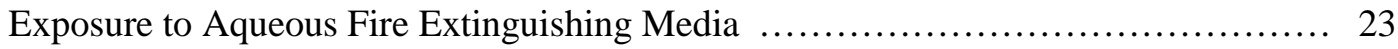

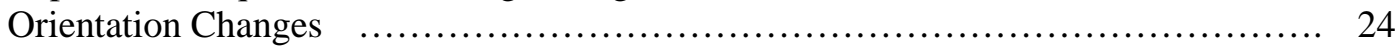

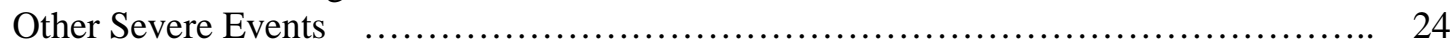

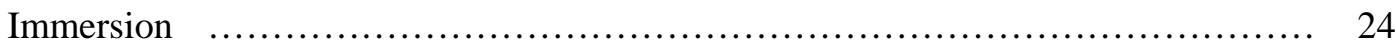


Loss of Thermal Management System or Insulation ............................. 25

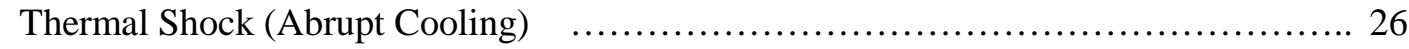

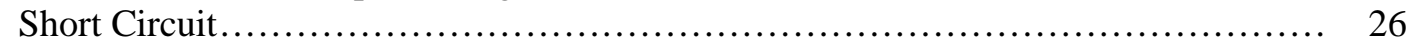

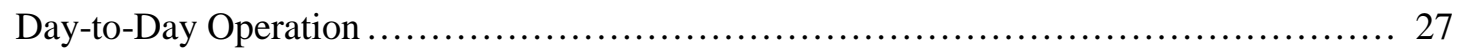

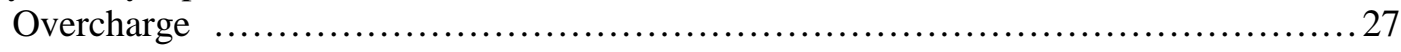

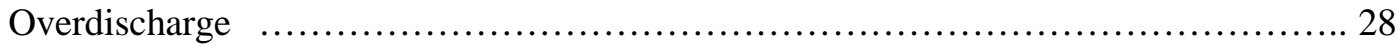

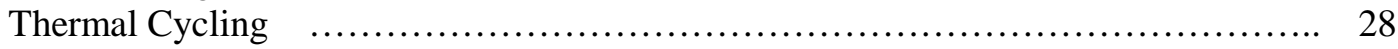

Ambient Temperature Extremes .............................................. 29

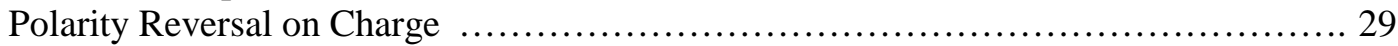

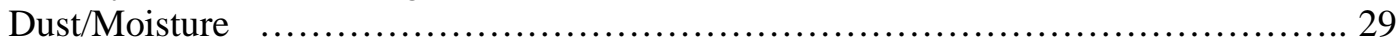

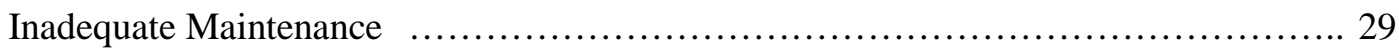

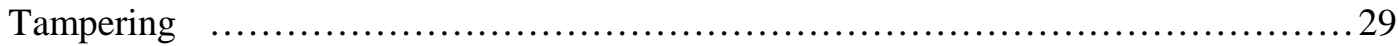

Vibration ...................................................................... 30

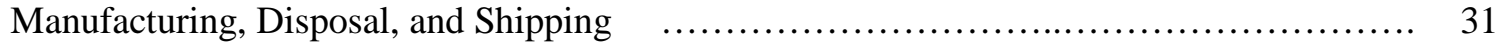

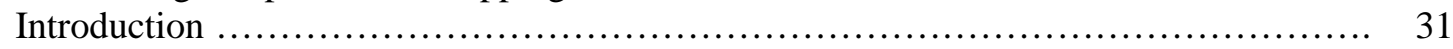

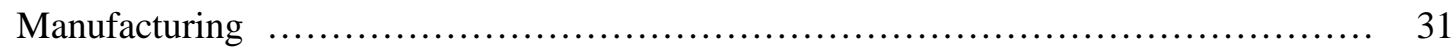

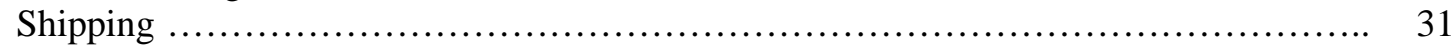

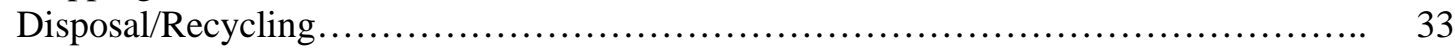

Summary and Recommendations $\quad$............................................. 34

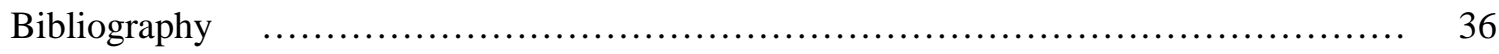

Appendix: Toxicities and Reactivities of Chemical Elements and

Compounds Potentially Associated with Sodium/Metal Chloride Batteries ................... 40 


\section{Introduction}

\section{Brief History and Definition of Topic}

The sodium/metal chloride electrochemical cell was patented in 1975 by John J. Werth of ESB Incorporated. ${ }^{1}$ Development of sodium/metal chloride electrochemical cells for application in electric storage batteries began in 1978, with the efforts of Johan Coetzer at the Council for Scientific and Industrial Research (CSIR) in Pretoria, ${ }^{2}$ with specific effort directed to configurations using an iron chloride positive electrode in a liquid electrolyte, sodium tetrachloroaluminate, separated from a negative sodium electrode by a ceramic electrolyte, sodium beta-alumina. Betaalumina's ionic conductivity had been discovered 16 years before by Joseph Kummer and Neil Weber, in the course of their work on sodium sulfur cells, ${ }^{3}$ a related but substantively distinct technology.

Batteries using the $\mathrm{Na} / \beta$-alumina $/ \mathrm{NaAlCl}_{4} /$ metal dichloride cell configuration (briefly, sodium/ metal chloride) are colloquially referred to as "Zebra" batteries or the "Zebra System," in recgnition of their South African origin and as an acronym for "zero emission battery research activity." Development of the technology progressed with the involvement of Harwell Laboratory and Beta Research and Development in England, and the CSIR and Zebra power Systems in South Africa. ${ }^{6}$ Additional independent research on the technology has been conducted by researchers at Argonne National Laboratory. ${ }^{7}$ Pilot-line production and development is presently being undertaken by AEG Zebra Marketing, Germany, under the ZEBRA trademark. ${ }^{8}$

This report addresses environmental, health, and safety (EH\&S) issues associated with sodium/ metal chloride batteries, in general, although most references to specific cell or battery types refer to units developed or being developed under the Zebra trademark. The report focuses on issues pertinent to sodium/metal chloride batteries and their constituent components; however, the fact that some "issues" arise from interaction between electric vehicle (EV) and battery design compels occasional discussion amid the context of EV vehicle design and operation. This approach has been chosen to provide a reasonably comprehensive account of the topic from a cell technology perspective and an applications perspective.

\footnotetext{
${ }^{1}$ U.S. Patent \#3877984, April 15, 1975. The patent was filed for on April 24, 1974, and makes reference to previous patents: \#3663295 (May 1972, by Baker) and \#3751298 (August 1973, by Senderoff). The patent, entitled Alkali Metal-Metal Chloride Battery, is relatively broad, describing an alkali metal negative electrode, a selectively ionically conductive solid separator, a molten salt electrolyte, and a metal chloride positive electrode. Glass, $\beta$-aluminas, and other cation conductive ceramics are referenced, and antimony is the preferred positive electrode metal.

${ }^{2}$ Sudworth (1998), p. 1.

${ }^{3}$ Sudworth (1998), p. 1.

${ }^{4}$ Superficially, the technologies may appear to be somewhat similar; however, they are fundamentally different in many key respects, notably, with respect to this report, in regard to certain safety aspects.

${ }^{5}$ Sudworth (1994), p. 95, indicates that the term refers to the location of early development work. Others familiar with the technology (e.g., Shemmans) indicate that the term is also officially an acronym, as stated in the text.

${ }^{6}$ Wedlake et al. (1988), p. 159

${ }^{7}$ For example, investigation of means of improving specific power and energy, via chemical additives and a tailored electrode morphology. See: Prakash, Redey, Nelson and Vissers (July 1996).

${ }^{8}$ Dustmann and Tilley (1996), p. 113. Approximately 170 batteries are being field and bench tested, including use on more than half the vehicles in the German EV test fleet on the island of Rugen.
} 
References to cells or batteries in this report are of three levels of specificity: (1) sodium/metal chloride, referring to the general technology at a wide level; (2) sodium/nickel chloride, sodium/ iron chloride, or sodium/nickel-iron chloride, referring to cells or batteries using specific cathodes; and (3) Zebra or Zebra system, referring to those cells and batteries being specifically developed by AEG Zebra Marketing, Germany. 


\section{Chemistry, Components, and Intrinsic Hazards}

\section{Cell Chemistry and Operation}

Sodium/metal chloride cells bear some similarity to those of sodium/sulfur battery systems in that both technologies operate at relatively high temperatures, both use a negative electrode composed of liquid sodium, and both use a $\beta$ or $\beta$ "-alumina solid electrolyte to separate this electrode from the positive electrode. ${ }^{9}$ However, sodium/metal chloride cells include a secondary electrolyte of molten sodium tetrachloroaluminate $\left(\mathrm{NaAlCl}_{4}\right)$ in the positive electrode section and an insoluble transition metal chloride $\left(\mathrm{FeCl}_{2}\right.$ or $\left.\mathrm{NiCl}_{2}\right)$ or a mix of such chlorides, as the positive electrode. The molten salt electrolyte (often referred to as a melt) serves to conduct sodium ions from the solid electrolyte to the metal chloride reaction site. ${ }^{10}$

The overall chemistry of these cells, during normal operation can, for nickel or iron monometallic cathodes, be summarized as:

\begin{tabular}{|c|c|c|c|}
\hline $\begin{array}{l}\text { Charged } \\
\mathrm{FeCl}_{2}+2 \mathrm{Na}\end{array}$ & $\begin{array}{c}200^{\circ}-300^{\circ} \mathrm{C} \\
\Leftrightarrow\end{array}$ & $\begin{array}{r}\text { Discharged } \\
\mathrm{Fe}+2 \mathrm{NaCl}\end{array}$ & $\mathrm{Eo}=2.35 \mathrm{~V} @ 250^{\circ} \mathrm{C}$ \\
\hline Charged & $200^{\circ}-400^{\circ} \mathrm{C}$ & Discharged & \\
\hline $\mathrm{NiCl}_{2}+2 \mathrm{Na}$ & $\Leftrightarrow$ & $\mathrm{Ni}+2 \mathrm{NaCl}$ & $\mathrm{Eo}=2.58 \mathrm{~V} @ 300^{\circ} \mathrm{C}^{11}$ \\
\hline
\end{tabular}

The site of reaction in the positive electrode section of the cell proceeds toward this electrode's core, starting from the interface between it and the solid electrolyte. At the beginning of discharge, cell resistance is at its minimum, and sodium ions from the $\beta$ "-alumina are conducted by the melt to reaction sites at what is essentially the surface or front of the electrode, adjoining the $\beta$ "-alumina. For a nickel chloride cell the reaction proceeds with the $\mathrm{NiCl}_{2}$ being reduced to metallic $\mathrm{Ni}$, and the formation of $\mathrm{NaCl}$. As the discharge continues, the reaction zone migrates deeper into the electrode section, toward the current collector and away from the $\beta$ "-alumina. Electrons are carried from the current collector to the reaction site via pathways of electrically conductive metallic nickel created as the reaction proceeds. ${ }^{12}$ In cells using an iron positive electrode, the reaction is essentially the same-with iron taking the place of the nickel and a moderate difference in voltage.

The charge reaction also begins at the $\beta$ "-alumina interface, with the reaction site moving inward toward the positive electrode current collector. One resulting benefit is that cell resistance during discharge is relatively low even if it is undertaken after only a partial charge. ${ }^{13}$

Although current may be drawn from the cells at approximately $170^{\circ} \mathrm{C}$, a little above the melting point of the $\mathrm{NaAlCl}_{4}$ (liquid) electrolyte, $\beta$ "-alumina has a relatively high resistance at this temperature, necessitating the higher temperature ranges indicated above for optimal operation

\footnotetext{
${ }^{9}$ See section on sodium $\beta$-alumina for reference to various species of this material.

${ }^{10}$ Vissers et al. (1988), p. 32-2.

${ }^{11}$ Dell and Bones (1988), p. 127.

${ }^{12}$ Dell and Bones (1987), p. 95. Only about $30 \%$ of the nickel in the cell is actually used in the electrochemical reaction.

${ }^{13}$ Dell and Bones (1987), p. 95.
} 
with large currents. ${ }^{14}$ Cells using $\mathrm{NiCl}_{2}$ cathodes have a wider operating temperature range than their iron-based counterparts. ${ }^{15}$

Although wider operating ranges are technically possible, the normal operating range of batteries using these cells is $270^{\circ} \mathrm{C}$ to $350^{\circ} \mathrm{C}$. When the thermal energy contained within the battery is used to heat the passenger compartment, the temperature may be permitted to drop to $250^{\circ} \mathrm{C}$, although charging is carried out at $270^{\circ} \mathrm{C} .{ }^{16}$

The theoretical specific energy of a nickel chloride cell is $790 \mathrm{Wh} / \mathrm{kg}$; this is without safety amendments such as the insulated battery case. Current practical batteries are reported to have values of approximately $100 \mathrm{Wh} / \mathrm{kg} .{ }^{17}$ For comparison, note that the U.S. Advanced Battery Consortium has established mid-term and long-term battery goals of 100 and $200 \mathrm{Wh} / \mathrm{kg}$, respectively. ${ }^{18}$

Until very recently, the batteries under development by AEG used cells with nickel chloride positive electrodes. As of this writing, cells use an approximately 4:1 nickel-iron mix, with an additional small quantity of aluminum. The nickel-iron modification was made to increase the specific power characteristics of the cells (particularly at high depths of discharge). The addition of aluminum imparts a degree of overdischarge capability over and above any conferred by undervaluing the "nameplate" capacity of the cells with respect to their actual physical characteristics. $^{19}$

Most of the information available on the Zebra system refers to cells using monometallic cathodes, hence, NREL asked Zebra developers if the new cells differed from the all-nickel designs with respect to safety. The response, provided below, was an emphatic no.

The latest nickel-iron cells have undergone and passed all the routine cell qualification tests (crushing, overcharge, over-temperature, etc.). Several nickel-iron batteries have also been safety tested on the standard tests (impact, short circuit, melt pour, vibration, etc.). We have found the safety behaviour of the new nickel-iron cells and batteries no different from the all-nickel cells. ${ }^{20}$

Reputable authorities familiar with the system but bearing no commercial interest in it concur with this assessment. ${ }^{21}$

\footnotetext{
${ }^{14}$ Dell and Bones (1988), p. 127.

${ }^{15}$ Van Zyl and Dustmann (1995), pp. 58, 60.

${ }^{16}$ Faxed comments from Jim Sudworth (Beta Research and Development, Ltd.) 9/29/98.

${ }^{17}$ Dell and Bones (1987), p. 94.

${ }^{18}$ Prakash et al. (1996), p. 1.

${ }^{19}$ Personal communications with Donald Vissers (ANL) 9/24/98, Gary Henrickson (ANL) 9/24/98, and Jim Sudworth (Beta Research and Development, Ltd.) 9/29/98. Additional information about discharge is presented later in the report. Undervaluing capacity or other ratings in order to ensure that users do not inadvertently tax a mechanism or product's true capabilities is a good and standard engineering practice.

${ }^{20}$ Memorandum from Roger Tilley (Beta Research and Development, Ltd.) 10/22/98.

${ }^{21}$ Personal communications with Donald Vissers (ANL) 9/24/98, and Laszlo Redey (ANL) 9/30/98.
} 


\section{Cell and Component Design}

\section{Background}

At operating temperature, a charged sodium/metal chloride cell consists of a liquid sodium electrode, a porous chlorinated metal electrode saturated with a molten salt electrolyte, a solid elecrolyte, and ancillary components such as the casing and seals. Batteries include the cells, by definition, as well as additional components such as enclosures, insulating materials, and elements of the thermal and charge management systems. There are three basic cell design options, yielding eight basic cell types. These are: [1] cathode type (iron, nickel, or mixtures); [2] negative anode design (central sodium or external sodium); and [3] orientation (vertical or horizontal). ${ }^{22}$ There are additional variations for each of the eight cell types, providing a high degree of flexibility in cell design and for custom applications. Zebra cells under development are of the nickel-iron cathode, external sodium, vertical orientation type, as depicted in Figure 1.

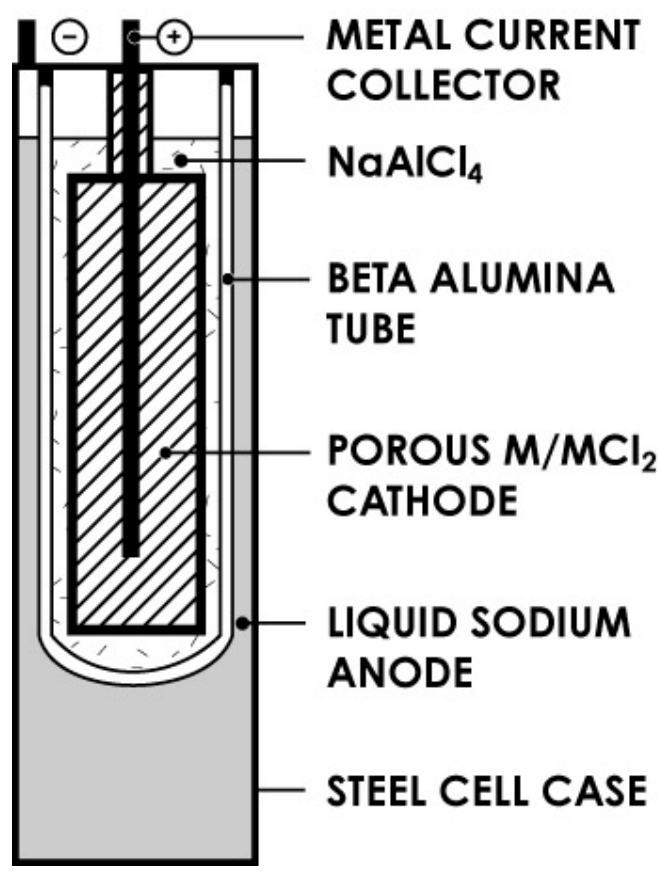

Figure 1. Zebra Cell-Central Cathode Configuration

Following is a description of essential cell components and their associated hazards. A general description of the characteristics and hazards of materials associated with Zebra cells is provided in the appendix. This discussion will focus primarily on cells using nickel electrodes. Batteryrelated components and hazards are addressed in the subsequent section.

${ }^{22}$ Dell and Bones (1988), p. 129. 


\section{Positive Electrode}

The positive electrode is manufactured, in the discharged state, from a mixture of common salt $(\mathrm{NaCl})$ and metal (nickel, or nickel and iron, and small quantities of aluminum) in the form of granulated powder, ${ }^{23}$ distributed around a nickel or copper-nickel collector. ${ }^{24}$ The initial charge oxidizes the nickel (or metal mix) and decomposes the $\mathrm{NaCl}$ to sodium and chloride ions, with the chloride ions combining with the oxidized metal to form a porous metal chloride electrode. Discharge results in the reverse reaction, leaving $\mathrm{NaCl}$ and metallic nickel. ${ }^{25}$ In the case of a mixed metal electrode, the chlorinated nickel is reduced first, then the chlorinated iron. ${ }^{26}$ The positive electrode (as well as other cell components) can be customized according to application requirements. Generally, high porosity and thinness are favored for high-rate applications such as EV traction. There is also a trade-off between the capacity for high power output and high specific energy. ${ }^{27}$

The primary materials contained in the positive electrode are $\mathrm{Ni}, \mathrm{Fe}, \mathrm{Al}, \mathrm{NiCl}_{2}, \mathrm{FeCl}_{2}$, and $\mathrm{NaCl}$. The liquid electrolyte, sodium tetrachloroaluminate ${ }^{28}\left(\mathrm{NaAlCl}_{4}\right)$, is in the electrochemical sense separate from the other cell components. However, it resides amidst the pores of the positive electrode and is contained within this cell compartment-which is defined by the interior walls of the ceramic electrolyte. Sodium tetrachloroaluminate melts at $157^{\circ} \mathrm{C}$ and serves to conduct sodium ions between the positive electrode ${ }^{29}$ and the ceramic electrolyte tube. ${ }^{30}$

\section{Sodium $\beta$ "-Alumina Ceramic Electrolyte}

Sodium beta alumina is an impermeable, white ceramic produced from oxides and hydroxides of aluminum, sodium, and lithium. ${ }^{31}$ There is more than one species of this material; the two most important for use as solid electrolytes are designated $\beta$ - and $\beta$ "-alumina. Of these, $\beta$ " is preferred because of its higher ionic conductivity. ${ }^{32} \beta$ "-alumina does not conduct electrons, ${ }^{33}$ has a high melting point $\left(2,000^{\circ} \mathrm{C}\right),{ }^{34}$ and is hydroscopic, eventually deteriorating in water. ${ }^{35}$ The chemical composition of the species used in the Zebra system is: $\mathrm{Na}_{1.7} \mathrm{Li}_{0.3} \mathrm{Al}_{10.7} \mathrm{O}_{17} ;{ }^{36}$ however, most chemical references made to it in the sodium battery literature refer to it as $\beta "-\mathrm{Al}_{2} \mathrm{O}_{3}$.

\footnotetext{
${ }^{23}$ Sudworth (1988), pp. 2,3. A sodium/nickel cell with a central sodium anode design requires a nickel cell case, therefore, when cost is a significant consideration, the central cathode design this report focuses on is preferred.

${ }^{24}$ According to Jim Sudworth (of Beta Research and Development, Ltd.), the latest ZEBRA ${ }^{\mathrm{TM}}$ cells use a nickel-coated copper-cored current collector (personal communications, 9/1/98, 9/29/98).

${ }^{25}$ Dustmann and Tilley (1996), p. 113.

${ }^{26}$ Personal communication with Jim Sudworth (of Beta Research and Development, Ltd.), 9/29/98.

${ }^{27}$ Dell and Bones (1988), p. 129. It is worth noting that the higher open circuit voltage characteristic of nickel chloride cells imbues it with a power advantage over the iron chloride design since, given cells of identical resistance, power output varies with the square of cell voltage.

${ }^{28}$ Also referred to as aluminum sodium tetrachloride in some material safety data sheets.

${ }^{29}$ Specifically, the reaction site within it.

${ }^{30}$ Nicholson et al. (1988), pp. 549,550.

${ }^{31}$ Scholz (1993), p. 10.

${ }^{32}$ Barrow (1988), p. 16-1.

${ }^{33}$ Dustmann and Tilley (1996), p. 114.

${ }^{34}$ Ionotec Ltd. Material Data Safety Sheet

${ }^{35}$ Personal communication with Jim DeGruson (Eagle-Picher Industries) 9/24/98.

${ }^{36}$ Ionotec Ltd. Material Data Safety Sheet
} 
In Zebra cells the $\beta$ "-alumina electrolyte is shaped in the form of a tube with a rounded, closed end-roughly similar to a laboratory test-tube. Its function is twofold: (1) to provide a physical separator preventing direct chemical reactions between electrode constituents; and (2) to serve as an ion conductor between the electrodes it separates. ${ }^{37}$ Like the positive electrode it can be customized according to specific cell requirements. ${ }^{38}$ In recent designs the $\beta$ "-alumina tube has a clover shaped, rather than circular cross section, to increase the surface area available for ion transfer. ${ }^{39}$ The $\beta$ "-alumina tube is covered by a $0.1-\mathrm{mm}$ thick mild steel sheath to facilitate sodium wicking along the surface of the $\beta$ "-alumina tube, and thus ensure a consistent density of ion flow through the tube, at different portions along its surface. ${ }^{40}$

\section{Negative Electrode}

The negative electrode consists of sodium metal in liquid phase (melting at $97.8^{\circ} \mathrm{C}$ ) and is contained within (and defined by) the cell casing and exterior of the $\beta$ "-alumina tube. Sodium is odorless, and has a light, silvery-white appearance. Like the other alkali metals, it is highly reactive, and never occurs naturally in the metallic state. Virtually any substance that can be reduced will be so in the presence of sodium or the other alkali metals. Liquid sodium has a low viscosity and will readily flow into cracks or surface perturbations in vessels containing it.

Current Zebra cells are typically manufactured without handling or using metallic sodium, since the sodium constituting the negative electrode is obtained from the electrolysis of sodium chloride in the positive electrode compartment during charging. This aspect of fabrication has significant safety and related implications for the manufacturing phase of the cells' life cycle, as well as for cell recycling or dismantlement. ${ }^{41}$ Although it is possible to acquire additional overdischarge capacity by adding additional sodium to the anode during manufacture, this capacity is presently achieved, as noted previously, by including a small amount of aluminum (and additional sodium chloride to match the aluminum) to the cathode during manufacture. ${ }^{42}$

\section{Additives}

Dopants may be added to different cell components to improve performance or longevity. These include small amounts of powdered iron, sodium fluoride, and iron sulfide in the positive electrode and a thin coating of carbon and phosphate on the exterior of the $\beta$ "-alumina electrolyte to improve sodium wetting. ${ }^{43}$

Trace amounts of aluminum are added to the anode to combine with or "tie up" the oxygen component of the air present in it during manufacture and when the cell is sealed. That is, the aluminum combines with that volume of atmospheric oxygen in the anode compartment when the cell is sealed and then brought to operating temperature. It remains bound with the oxygen (leaving only the nitrogen) through the life of the cell, and may be considered from the standpoint of cell operation, like the nitrogen, inert.

\footnotetext{
${ }^{37}$ Moseley et al. (1992), p. 1361.

${ }^{38}$ Sudworth et al. (1987), p. 1114.

${ }^{39}$ Personal communication with Jim Sudworth (Beta Research and Development, Ltd.) 9/01/98.

${ }^{40}$ Personal communication with Jim Sudworth (Beta Research and Development, Ltd.) 9/01/98.

${ }^{41}$ Sudworth (1994), pp. 95, 100.

42 The functions of the aluminum and additional sodium chloride are described in the section on overdischarge.

${ }^{43}$ Personal communication with Jim Sudworth (Beta Research and Development, Ltd.) 9/01/98.
} 
Bromine, a substance with significant EH\&S issues, has been experimented with by various sodium/metal chloride system designers, and could conceivably find its way back into future cells; however it is not currently used or envisioned in Zebra cells. ${ }^{44}$

\section{Other Cell Materials}

Depending on cell configuration, either nickel or mild steel is used for cell casings, ${ }^{45}$ and mild steel, nickel, or nickel-coated copper is used for the current collector. ${ }^{46}$ Cells are hermetically sealed with a thermal compression bond (TCB) ceramic/metal seal. ${ }^{47}$ The seal consists of a metallised alpha alumina sealing ring to which the nickel components are diffusion bonded. ${ }^{48}$

\section{Intrinsic Material Hazards, Independent of Cell Design and Operation}

\section{Background}

Nickel, nickel chloride, ferrous chloride, sodium, and some cell additives are potentially hazardous. The actual severity and nature of risk imposed depend on specific circumstances such as period and type of exposure, and factors such as the presence of ignition sources or incompatible substances such as strong acids. Thus, the actual risk imposed by these materials is greatly dependent on the design of the cell and/or battery incorporating them, and to a lesser degree, factors presented by their application environment. The following section discusses the hazards intrinsic to the component materials in each section of the cell. ${ }^{49}$ Hazards that result from cell design or operation are addressed in later sections.

\section{Positive Electrode}

Nickel metal and nickel chloride are considered hazardous and should be handled according to appropriate safety guidelines. ${ }^{50}$ Nickel powder supports combustion, and may form explosive mixtures in air. It should not be allowed to come into contact with mineral acids and strong oxidizers. Acute and chronic health hazards may include the development of transient pneumonitis or asthma-like symptoms, itching, rash, inflammation, and sensitive dermatitis. ${ }^{51}$ There is considered to be limited evidence for the carcinogenicity of nickel and certain nickel compounds in humans, with an actual cancer hazard being associated with the early stage of nickel refining. ${ }^{52}$

Nickel chloride does not support combustion and is not considered to be a fire hazard, nor is it considered to be particularly reactive, though it should not be allowed to come into contact with potassium. ${ }^{53}$ Acute and chronic health hazards may include dermal, eye, and respiratory irritation,

\footnotetext{
${ }^{44}$ Personal communications with Jim Sudworth (Beta Research and Development, Ltd.) 9/29/98, and Laszlo Redey (ANL) 9/30/98.

${ }^{45}$ Sudworth (1988), pp. 2, 3.

${ }^{46}$ Personal communication with Jim Sudworth (Beta Research and Development, Ltd.) 9/01/98.

${ }^{47}$ Dustmann and Tilley (1996), p. 114.

${ }^{48}$ Faxed memorandum from Jim Sudworth (Beta Research and Development, Ltd.) 9/29/98.

${ }^{49}$ A more complete listing of the characteristics and hazards associated with the cell components is presented in the appendix of this report.

${ }_{50}^{50}$ Material Safety Data Sheet, Mallinckrodt Baker, Inc.

${ }^{51}$ Material Safety Data Sheet, Mallinckrodt Baker, Inc.

${ }^{52}$ Report on Carcinogens, $8^{\text {th }}$ Edition, "Nickel and Certain Nickel Compounds"

${ }^{53}$ Material Safety Data Sheet, Mallinckrodt Baker, Inc.
} 
and may cause allergic reactions. It is also considered to be a cancer hazard; cancer risk depends on duration and level of exposure. ${ }^{54}$

The hazardousness of iron metal is dependent upon the physical form it is in. In the form of ultrafine powder (ca. 5 microns) it is pyrophoric and can ignite spontaneously in air. Iron dust can also react with water, liberating flammable hydrogen gas. Thus, water should not be used as a fire extinguishing agent; nor should carbon dioxide or dry chemical extinguishing agents be used. MSDS sheets recommend instead powdered graphite, powdered salt, or powdered limestone.

Iron may cause irritation to the respiratory tract, and when ingested in extremely large doses, may cause gastrointestinal disturbances, lethargy, and shock. Skin exposure does not result in adverse effects; however, eye exposure can result in redness and pain, and deposition of iron particles can leave a "rust ring" or brownish stain on the cornea.

Ferrous chloride $\left(\mathrm{FeCl}_{2}\right)$ is a greenish-white-yellow deliquescent crystalline substance. It should be kept away from fire and other ignition sources. If exposed to sodium, it may undergo exothermic polymerization, resulting in a violent explosion. ${ }^{55}$ Its thermal decomposition products may include toxic and corrosive chlorine fumes. Fire extinguishing media appropriate for this material are: dry chemical, $\mathrm{CO}_{2}$, halon, water spray, foam, and fog. ${ }^{56}$

Dermal exposure to ferrous chloride may result in irritation, burns, dermatitis, and poisoning through absorption. Inhalation may cause difficult breathing and irritation of the mucous membranes. Ingestion may cause a range of effects including, gastrointestinal disorders, leukocytosis, cyanosis, cardiovascular collapse, liver/kidney/pancreatic damage, and possible death. ${ }^{57}$ It is not considered to be a carcinogen. ${ }^{58}$

Sodium chloride is not considered to be particularly hazardous, though it may irritate the skin and eyes, and ingestion of large quantities may irritate the gastrointestinal tract. ${ }^{59}$

Sodium tetrachloroaluminate is formed by heating an equimolar mixture of sodium chloride and aluminum chloride. It is reactive with water, and in the presence of water will corrode steel. ${ }^{60}$ Exposure to high enough temperatures in the presence of moisture may result in the formation of $\mathrm{HCl}$, followed, possibly by the formation of chlorine gas. ${ }^{61}$

\section{Sodium $\beta$ "-Alumina Ceramic Electrolyte}

Sodium $\beta$ "-alumina $\left(\mathrm{Na}_{1.7} \mathrm{Li}_{0.3} \mathrm{Al}_{10.7} \mathrm{O}_{17}\right)$ is incombustible, nonreactive, and is not known to present any health hazards beyond irritation to the eyes and respiratory system upon exposure to high concentrations of dust. ${ }^{62}$

\footnotetext{
${ }^{54}$ Material Safety Data Sheet, Mallinckrodt Baker, Inc.

${ }^{55}$ Material Safety Data Sheet, Occupational Health Services, Inc.

${ }^{56}$ Material Safety Data Sheet, Fisher Scientific, Chemical Division

${ }^{57}$ Material Safety Data Sheet, Occupational Health Services, Inc.

${ }^{58}$ Material Safety Data Sheet, Fisher Scientific, Chemical Division

${ }^{59}$ Material Safety Data Sheet, Fisher Scientific

${ }^{60}$ Personal communication with Jim Sudworth (Beta Research and Development, Ltd.) 9/01/98.

${ }^{61}$ Personal communication with Jim DeGruson (Eagle-Picher Industries) 9/24/98.

${ }^{62}$ Material Data Safety Sheet, Ionotec Ltd.
} 


\section{Negative Electrode}

Sodium metal is highly reactive. It is flammable in a normal atmosphere, corrosive, and exothermically reactive with water, releasing hydrogen gas that is ignited by the heat of the reaction. It presents internal and external health hazards, including the risk of burns and irritation to the mucous membranes and respiratory tract. Sodium fires burn violently and may be accompanied by explosions that splatter the molten metal. Fires should be suppressed with dry soda ash, salt, sand, or metal-fire-extinguishing powder such as Met-L-X. ${ }^{63}$

\section{Additives}

Powdered aluminum does not pose health hazards beyond physical dust irritation, and is stable under ordinary conditions of use and storage. However, it is moderately flammable, and can produce hydrogen when exposed to water.

Sodium fluoride can irritate tissue if inhaled or ingested, resulting in acute nausea, gastrointestinal maladies, coma, weakness, and tremor. Sodium fluoride is stable, and not considered to pose a fire hazard, but will react with acids to form corrosive hydrofluoric acid. ${ }^{64}$

Iron sulfide is considered stable under normal temperatures and pressures, but should not be combined with strong acids or oxidants, since sulfur oxides and hydrogen sulfide may be produced as a result. ${ }^{65}$ Iron sulfide dust may cause physical irritation, but it is not known to have carcinogenic or toxicological effects, beyond being a possible source of irritation to the respiratory and digestive tracts. ${ }^{66}$

Carbon is not considered to pose health or safety hazards, although it may spontaneously combust if exposed to strong oxidizers, e.g., liquid oxygen. ${ }^{67}$

Phosphates may cause skin and eye irritation as a result of exposure. When heated to decomposition they may release toxic fumes (of phosphoric compounds). However, they are not considered to pose unusual fire or explosion hazards. ${ }^{68}$

\section{Other Cell Materials}

Materials such as copper, aluminum, mild steel, and the alumina used in the seals do not pose significant intrinsic safety or health hazards.

\section{Hazards Occurring during Normal Operation}

Zebra cells are contained within a hermetically sealed steel case, which makes exposure to nickel, nickel compounds, ferrous chloride, or sodium impossible during normal operation. The cells do not vent gases or other substances during normal operation, and do not contain materials characterized by high vapor pressures at the temperature ranges associated with such operation.

\footnotetext{
${ }^{63}$ Material Safety Data Sheet, Mallinckrodt Baker, Inc.

${ }^{64}$ Material Safety Data Sheet, Chemical Commodities Agency.

${ }^{65}$ Material Safety Data Sheet, Acros Organics

${ }^{66}$ Material Safety Data Sheet, Acros Organics

${ }^{67}$ Material Safety Data Sheet, Calgon Carbon Corporation.

${ }^{68}$ Material Safety Data Sheets, FMC Corporation; Fisher Scientific.
} 
Hence, phase-change induced pressure differentials, which could result in seal failure or breached casings, do not develop under normal conditions.

Likewise, the reactions that occur during normal operations do not result in gaseous products that must be contained, or in the release of dangerous amounts of heat. Those reactions that do take place are well known, well characterized, and because of the cell construction previously described, do not pose impose EH\&S risks during normal operation.

Approximately 170 Zebra batteries are being field and bench tested, including those used on over half of the vehicles in the German electric vehicle test fleet on the island of Rügen. ${ }^{69}$ This realapplication testing should provide additional data with which to evaluate battery safety during daily operation.

${ }^{69}$ Dustmann and Tilley (1996), p. 113. 


\section{Hazards Resulting from Internal Failure}

\section{Background-Zebra and Sodium/Sulfur Cells}

Zebra cells are sometimes regarded as sodium sulfur cells in which the sulfur has been replaced with nickel or iron. ${ }^{70}$ This is in some aspects true, but substituting chlorinated nickel or iron in the positive electrode has profound safety impacts. Much of the challenge of creating safe sodium/ sulfur cells derives from the immense need to prevent contact between the sulfur and sodium electrodes, since these substances react violently. ${ }^{71}$ The hazards associated with this reaction, and the reactants themselves, were recognized by Hames and Tilley, who in 1975 defined a safe cell as one that "under all but the most improbable conditions, did not allow its reactive contents to escape in the event of call failure or accident," and enunciated three general principles for cell safety: (1) Minimize the quantity of sodium immediately available for reaction after failure of the ceramic electrolyte; (2) Separate the bulk of cell reactants, and minimize the flow of sodium to the reaction site; and (3) Protect the outer shell case (for sodium-cored cells) from corrosion by sodium polysulfides. ${ }^{72}$ This definition remains valid for Zebra cells, but the principles set forth to achieve it do not strongly apply to them since the consequences of failure of the $\beta$ "-alumina electrolyte in a Zebra cell are much less severe than those resulting in cells using sulfur electrodes. Moreover, some of the agents or mechanisms (e.g., corrosion of the cell case by polysulfides) affecting sodium/sulfur cells do not even exist in the Zebra system.

This section addresses the impacts of cell and battery system failures originating during operation, absent externally inflicted causes. Failures resulting from external events are addressed in the following section.

\section{$\beta$ "-Alumina Electrolyte}

The $\beta$ "-alumina electrolyte serves to physically separate the electrodes, preventing direct chemical reactions between their constituents, but allowing sodium ions to pass. ${ }^{73}$ Stability limits and breakdown mechanisms for $\beta$ "-alumina in sodium/sulfur and Zebra cells are essentially the same for the sodium side of the ceramic electrolyte, but very different for the cathode side. ${ }^{74}$

In the case of $\beta$ "-alumina fracture, the anode material (liquid sodium), being of low viscosity, ${ }^{75}$ flows readily through the cracks into the positive electrode chamber, and into contact with the molten electrolyte (sodium tetrachloroaluminate). The sodium reacts primarily with the molten electrolyte, as opposed to the positive electrode material (nickel and iron, or chlorinated nickel and iron) as would be the case in a sodium/sulfur cell. The reaction is:

$3 \mathrm{Na}+\mathrm{NaAlCl}_{4} \rightarrow 4 \mathrm{NaCl}+\mathrm{Al}$

\footnotetext{
${ }^{70}$ Wedlake et al. (1988), p. 159.

${ }^{71}$ Environmental, Health, and Safety Issues of Sodium-Sulfur Batteries for Electric and Hybrid Vehicles (1992), pp. 4,5.

${ }^{72}$ Environmental, Health, and Safety Issues of Sodium-Sulfur Batteries for Electric and Hybrid Vehicles, p. 5.

${ }^{73}$ Moseley et al. (1992), p. 1361.

${ }^{74}$ Moseley et al. (1992), p. 1361. See this source for a description of breakdown mechanisms for NaS cells.

${ }^{75}$ Dell and Bones (1988), p. 125.
} 
This reaction is mildly exothermic, releasing about two-thirds of the energy of the normal electrode reaction, ${ }^{76}$ and produces solid, nonhazardous, noncorrosive products with low vapor pressures. $^{77}$

Out-of-cell experiments were performed to determine the potential violence of the reaction between a charged positive electrode saturated with sodium tetrachloroaluminate, and liquid sodium. Sodium tetrachloroaluminate reacts with sodium if agitated with it, but in practical cells it resides in the porous structure of the positive electrode. This has the effect of reducing the reaction rate, and hence, reducing heat generation. When positive electrodes were inserted into liquid sodium at cell operating temperatures, there was no visible response. Temperature rose slowly and was limited to an increase of approximately $100^{\circ} \mathrm{C} .{ }^{78}$

Aluminum, besides being nonhazardous and nonreactive, is electrically conductive and solid at the operating temperature range. As a result, when a $\beta$ "-alumina fracture takes place in a sodium/ metal chloride cell, the aluminum resulting from the ensuing reaction creates a physical barrier that prevents further reaction. ${ }^{79}$ This prevents additional release of the electrochemical energy potentially available (resulting in a lower than potentially possible temperature rise), but allows electrical conductivity between the cathode and the anode. ${ }^{80}$ The formation of this electrically conducting barrier has additional significant safety implications since it allows for cells to be connected in series without parallel connections/cell failure shunts, and any complications or risks that might attend them. ${ }^{81}$ This also allows a large range of batteries to be designed using one standard (and presumably well-characterized) cell type. ${ }^{82}$

The fact that abnormally high temperatures would be required to induce phase changes (producing pressure differentials between the sealed cells and exterior environment) in both the normal cell constituents ${ }^{83}$ and these reaction products is particularly important from an EH\&S perspective. In the direct sense it means that Zebra cells-specifically, their steel cases and TCB sealsare unlikely to be subjected to internally generated pressure resulting from the application of heat, whether from internal malfunction or external sources. It is significant in an indirect sense because of the comparison it invites with sodium/sulfur cells. Under the same circumstance (fracture of the $\beta$ "-alumina electrolyte) sodium/sulfur cells must contend with a much more violent reaction, the creation of polysulfides, and the rapidly increasing vapor pressure of sulfur, after its boiling point, $717 \mathrm{~K}$. Sodium/sulfur cell designers are thus forced to resort to sodium flow-restricting mechanisms to hinder the reaction rate and anti-corrosion measures to protect the exterior casing. ${ }^{84}$

\footnotetext{
${ }^{76}$ If the reaction takes place within actual cells and results from ceramic fractures (as opposed to the reaction resulting from the simple, thorough mixing of the reactants), the aluminum solid so formed tends to separate the reactants and interrupt the reaction. This is discussed in a little more detail below.

${ }^{77}$ Van Zyl and Dustmann (1995), p. 62, Sudworth (1994), p. 97.

${ }^{78}$ Tilley and Holmes (1988), p. 54-2.

${ }^{79}$ Wedlake et al. (1988), p. 160.

${ }^{80}$ Personal communication with Dr. Donald Vissers, (ANL), 9/24/98.

${ }^{81}$ Dell and Bones (1988), p. 129.

${ }^{82}$ Sudworth (1994), p. 97.

${ }^{83}$ Dell and Bones (1988), p. 128.Vapor pressure is low up to $973 \mathrm{~K}$.

${ }^{84}$ Dell and Bones (1988), p. 125. Indeed, a significant problem with sodium/sulfur cells is the tendency for initial damage to the ceramic electrolyte to intensify as the heat released from the initial reaction of sulfur and sodium, and the high vapor pressure of sulfur asserts further stresses upon it.
} 
$\beta$ "-alumina is well characterized and is employed in a wide variety of applications. These range from fuel cells to filtration systems. ${ }^{85}$ Breakdown mechanisms continue to be studied, however, and in tests of cell tubes involving thousands of cycles, failed tubes demonstrated evidence of fracture but did not exhibit evidence of leakage. ${ }^{86} \beta$ "-alumina is expected to exhibit a longer lifetime in Zebra cells than in sodium/sulfur cells as a result of the absence of sulfur-related degradation problems such as deposition and corrosion. ${ }^{87}$

\section{Seals}

Two types of seals are discussed in reference to the Zebra system. The first, compression seals, were used in early cell versions, and could act as safety valves to vent gas in cases of overcharge, overdischarge, or overheating. Risks imposed by slight seal leakage could be reduced by surroundng the seal area with an absorbent material (e.g., a dehydrated zeolite) ${ }^{88}$ Compression seals are not used in current cells, however, since development has progressed to the point where they do not evolve gases, even under abusive conditions. ${ }^{89}$ Hermetic sealing can thus be used, lessening environmental risks. ${ }^{90}$

The hermetic seals used in Zebra cells employ a TCB or diffusion bond. They are inexpensive, simple in design, producible in mass quantities by automation, and long lived. For these reasons they were universally adopted in sodium/sulfur cells. ${ }^{91}$

Seal fatigue caused by excessive thermal cycling and/or vibration is considered unlikely. ${ }^{92}$ However, should it take place, either or both of the seal's concentric welding seams may open. ${ }^{93}$ Should the outer seam open, liquid sodium escapes from the cell and reacts with atmospheric oxygen to form solid sodium oxide. Typically, this solid blocks the opening and reseals the cell, preventing the further loss of sodium. If this fails to happen, oxygen diffuses into the negative electrode compartment of the cell, and the remaining sodium is oxidized, resulting in the gradual failure of the cell. ${ }^{94}$

If the inner seam fails, liquid sodium tetrachloroaluminate spills out of the cell and into the battery compartment. In earlier designs this spillage would overheat neighboring cells, the seals would be breached, and the process would continue-amounting to a controlled chain reaction. ${ }^{95}$ Current Zebra batteries have been redesigned, and incorporate a drainage system precluding this situation. ${ }^{96}$

Tests simulating such an incident were conducted by pouring 250 grams of sodium tetrachloroaluminate over a group of cells and observing the results. The result was the issuance of a small

\footnotetext{
${ }^{85}$ Electroceramic Products, Ionotec Ltd., http://ourworld.compuserve.com/homepages/ionotec/electroc.htm

${ }^{86}$ Sudworth (1988), p. 36-5.

${ }^{87}$ Sudworth et al. (1987), p. 1114

${ }^{88}$ Wedlake et al. (1988), p. 164.

${ }^{89}$ Prakash et al. (1996), p. 5. See the section of this paper addressing overcharging for additional discussion of gas formation.

${ }^{90}$ Prakash et al. (1996), p. 5.

${ }^{91}$ Bull and Bugden (1988), p. 33-2.

${ }^{92}$ Van Zyl and Dustmann (1995), p. 64.

${ }^{93}$ Van Zyl and Dustmann (1995), p. 64.

${ }^{94}$ Van Zyl and Dustmann (1995), p. 64.

${ }^{95}$ Van Zyl and Dustmann (1995), p. 64.

${ }^{96}$ Faxed memorandum from Dr. Harold Böhm, (AEG ZEBRA Battery Marketing GmbH), 10/7/98.
} 
amount of "white smoke" (presumably aluminum hydroxide). ${ }^{97}$ There was no damage to the battery other than to the immediate area exposed to the molten electrolyte. ${ }^{98}$

\section{Cell Casings}

The steel casings are not considered to be subject to internal failure and would probably resist failure longer than the hermetic seals in the case of a buildup of internal pressure. ${ }^{99}$ However, if the failure were caused by material fatigue, the results would be essentially the same as those described earlier for an outer seam seal failure. Zebra cells do not contain substances (such as polysulfides) that can attack the cell casing and compromise its containment function. ${ }^{100}$ The casings are relatively rugged, as discussed in the section on externally inflicted hazards, and not considered to be a weak link in the cell structure. ${ }^{101}$ Designers knowledgeable about the cells have found that any trauma capable of breaching the cell casing or seals will almost certainly also fracture the $\beta$ "-alumina. The resulting reaction between the melt and sodium (previously described) lessens the likelihood of sodium being released into the battery compartment. (Sodium released into the battery compartment would react with the oxygen within it, given the high temperature maintained therein. ${ }^{102}$

\section{Effect of Individual Cell Failures on Other Cells}

The tendency of cells to fail in an electrically conductive mode is desirable from an engineering perspective since it simplifies battery design and encourages the use of a single standardized cell for a wide range of battery capacities and voltages. In addition, this tendency also imparts desirable safety and reliability aspects by rendering unnecessary any need to include internal wiring to bypass cells in the case of failure. ${ }^{103}$ This characteristic, in combination with sophisticated charge management systems, has been shown to allow Zebra batteries to operate with as many as $5 \%$ of their cells in the failed mode, thus reducing repair and maintenance requirements. This redundancy results in the statistical lifetime of the batteries to be far greater than that of single cells. ${ }^{104}$

\section{Cell Failure Shunts (Looping Elements) between Cells}

Cell failure shunts, i.e., wiring connecting the cells within a battery, and used to bypass them in the case of failure, can present unique problems in high-capacity batteries. As previously discussed, however, the closed-circuit or low-resistance failure mode of Zebra cells has rendered them unnecessary in current Zebra batteries, and therefore removed them from discussion as a potential source of failure.

\section{Charge Regulation Mechanisms within the Battery}

Charge regulation mechanism failures can, from the cell's perspective, be treated as externally inflicted events. That is, conditions (e.g., overcharge, undercharge, short-circuit, reversed polarity charging, excess cycling, and similar conditions) that might arise from failure of the battery

\footnotetext{
${ }^{97}$ Bull and Bugden (1988), p. 115.

${ }^{98}$ Van Zyl and Dustmann (1995), p. 64.

${ }^{99}$ Personal communication with Malcom Shemmans, 7/28/98.

${ }^{100}$ Dell and Bones (1988), p. 97, Sudworth (1994), p. 128.

${ }^{101}$ Personal communication with Malcom Shemmans, 7/28/98.

${ }^{102}$ Faxed memorandum from Dr. Harold Böhm, (AEG ZEBRA Battery Marketing GmbH), 10-7-98.

${ }^{103}$ Personal communication with Laszlo Redey (ANL) 9/30/98.

${ }^{104}$ Dustmann (1998), p. 6.
} 
management system can be looked on as being inflicted on the cell. These events are therefore addressed in the externally inflicted events section.

\section{Insulation and Thermal Management System}

Thermal management system failures can also be treated as extraneous to the cell, and are addressed in the next section.

\section{Calendar and Cycle Life}

Although not regularly thought of in the context of EH\&S issues, calendar and cycle lifetimes are relevant because the complete failure of an electrically powered vehicle's battery can, depending on how quickly it proceeds, place its occupants at risk. ${ }^{105}$ The tendency of cells to fail in an electrically conductive mode reduces the likelihood of a complete failure of the battery. ${ }^{106}$ In addition, the cumulative EH\&S risks associated with providing an EV with a source of electrical energy increase with each battery replacement, since all batteries, regardless of design and components, impose a set of health or safety risks and environmental costs in the course of even uneventful construction, replacement, and recycling/retirement. Current Zebra batteries have demonstrated an in-vehicle lifetime of 4 years, 1,260 cycles, and 112,000 Km without cell replacement. ${ }^{107}$ Data indicate an in-vehicle lifetime of up to a decade, given the apparent absence of corrosion and other life-limiting effects. ${ }^{108}$

\footnotetext{
${ }^{105}$ Anyone who has ever experienced a fuel pump malfunction (or run out of fuel) while making a left turn across opposing traffic can appreciate the relevance of this statement.

${ }^{106}$ Dustmann (1998), p. 6.

${ }^{107}$ Dustmann and Tilley (1996), p. 113.

${ }^{108}$ Dustmann and Tilley (1996), p. 113.
} 


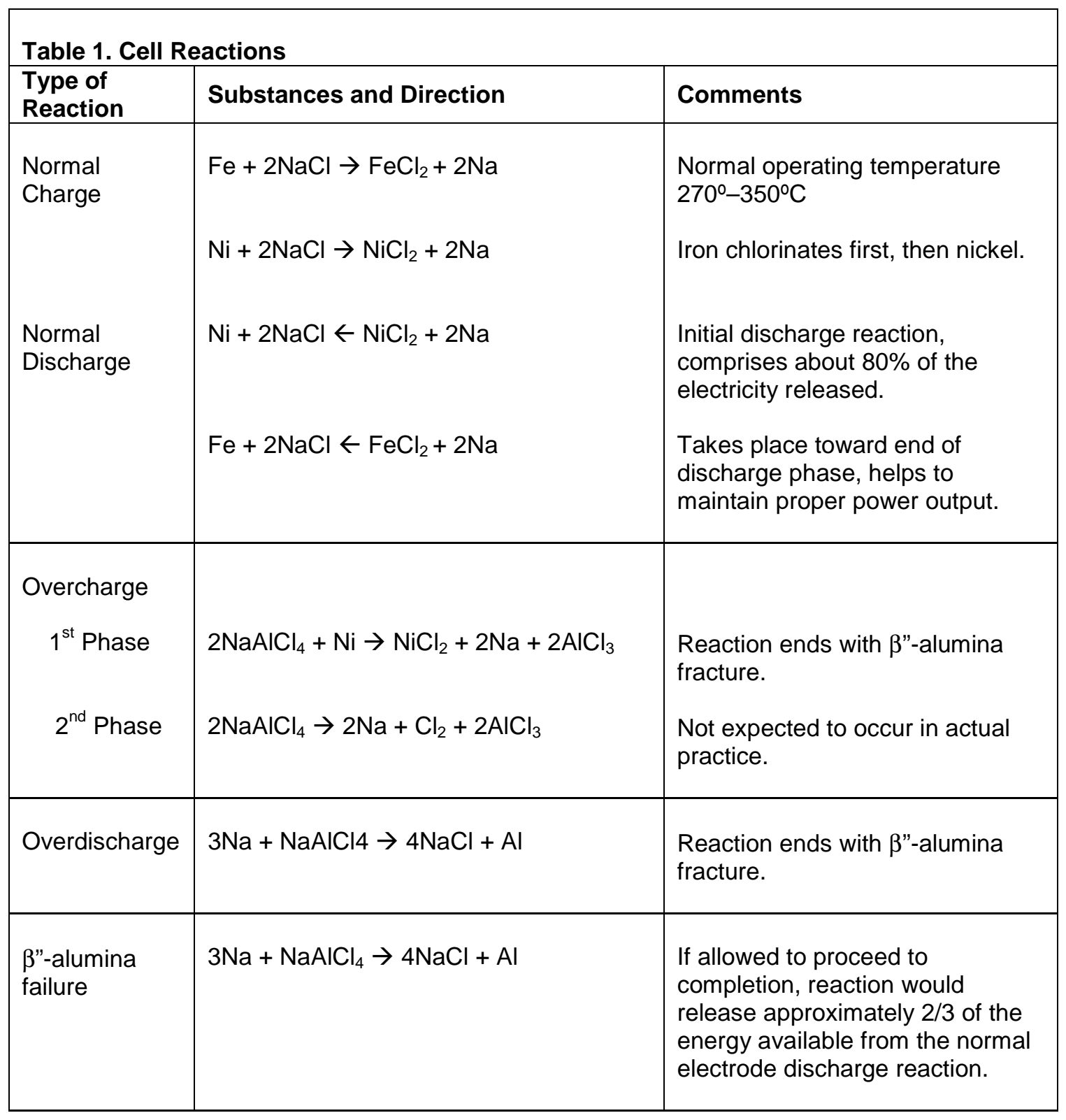




\section{Hazards Resulting from Externally Inflicted Influences}

\section{Background}

Electrochemical cells or batteries may fail because of internal causes such as fatigue or malfunction, or as the direct result of external influences. The external influences likely to affect an EV battery can be informally categorized as either extreme or mundane, depending on the expected frequency of occurrence, degree of damage to the battery or vehicle, or the amount of distress inflicted upon the vehicle to create the condition affecting the battery. Extreme events include collisions or "accidents" inflicting shock and/or physical damage, water immersion, and thermal shock. Day-to-day events include nonoptimal conditions which, although presumably unusual in the laboratory, might be expected to transpire during day-to-day operation. These include vibration, charge mishaps, thermal cycling, tampering, and other forms of abuse.

\section{Accident-Related Events}

\section{Background}

EV battery experts consider the potential consequences of accident-induced mishaps to be severe, whatever the battery technology. ${ }^{109}$ Given this assessment, shock, crushing/deformation, piercing, fire, and orientation changes are discussed under this heading, even though some may be relevant in different contexts.

Zebra cells are housed within a temperature-controlled, double-walled, sealed, vacuum-insulated battery case. This case or enclosure is intended to both protect the outside environment from the effects of mishaps within, and to protect internal battery components from hazards outside. ${ }^{110}$ Accidents resulting in the penetration of the casing can be expected to compromise its insulating and containment functions, and if severe enough, to rupture the cells contained inside.

Instances of cell failure may be delineated into two distinct modes: those in which the cell casing or seals are ruptured, and those in which the cell exterior remains intact. Cases in which cells fail with intact cell casings have relatively straightforward consequences. The $\beta$-alumina tube fractures, and relatively inconsequential amounts of heat are released, ${ }^{111}$ but no toxic or otherwise harmful substances are released into either the battery case or outside of it.

The other case, cell rupture or breaching, is potentially much more severe, given the reactive nature of sodium and, to a lesser degree, the chlorinated nickel/iron that may be present in the positive electrode. It has previously been emphasized that trauma capable of damaging a cell's casing or seal will almost certainly also fracture its $\beta$-alumina tube. ${ }^{12}$ Most or all of the sodium is "consumed" in the resulting reaction between it and the melt, leaving little or none to escape or

\footnotetext{
${ }^{109}$ Results of Electric Vehicle Safety Issues Survey, pp. 9-12.

${ }^{110}$ Dustmann and Tilley (1996), p. 114.

${ }^{111}$ This is not to maintain that the heat released is insignificant, but rather that it does not apparently pose hazards given the overall cell and battery designs.

${ }^{112}$ This occurrence is even more probable in the new cells since the $\beta$-alumina shape used in these cells is not as robust as that used in the older type. Source: Faxed memorandum from Dr. Harold Böhm, (AEG ZEBRA Battery Marketing GmbH), 10-7-98.
} 
otherwise impose hazards outside of the cell. ${ }^{113}$ Should some sodium, however, escape the cell it quickly reacts with the oxygen inside of the battery casing, given the high operating temperature of the battery. In 2 years of abuse testing, according to AEG ZEBRA, there have been no observations of the release of sodium from the battery casing. ${ }^{114}$

Current cells may, indeed, be hard-pressed to rupture or breach without the concomitant $\beta$ alumina failure discussed and so assumed. Nevertheless, a thorough examination must also examine the prospect, theoretical or not, in which rupture occurs with the $\beta$-alumina tube intact. The results mirror those discussed in the context of seal failure, with two general possibilities arising.

The first, although somewhat unlikely, given the configuration of the cell, ${ }^{115}$ is exposure of the melt to atmospheric moisture and its subsequent decomposition into aluminum hydroxide and hydrogen chloride, in trace amounts. Aluminum hydroxide is not considered to be particularly hazardous, but hydrogen chloride can be dangerous if present in high enough concentrations. ${ }^{116}$

The second possibility is the release or exposure of liquid sodium, and its subsequent oxidation to sodium oxide, a solid. Should this occur via a seal breach, the nascent sodium oxide blocks the opening and prevents further sodium loss. It is not known whether this "self-repair" mechanism would be active in the case of an opening in the cell casing, particularly one occurring at the middle or bottom of the cell; however, assuming it were not (an acknowledged possibility in the case of seal failure), the sodium would either: (1) gradually be converted to sodium oxide as oxygen diffused into the anode compartment through the rupture, resulting in the gradual failure of the cell ${ }^{117}$; or (2) spill into the battery compartment to react with oxygen there. Although the results of such spillage are not entirely clear, two points of information provide some insight.

First, overheating cells by a few hundred degrees above the normal operating temperature of $250^{\circ} \mathrm{C}$ has negligible effects. ${ }^{118}$ The constituents of Zebra cells have low vapor pressures below temperatures of approximately $800^{\circ} \mathrm{C} .{ }^{119}$ Theoretically at least, the only component that would be expected to vaporize near this temperature vicinity is sodium, with a boiling point of $882^{\circ} \mathrm{C}$. This is borne out by tests heating unevacuated cells to $800^{\circ}-1,000^{\circ} \mathrm{C}$. The results on different cell designs (20 tests per cell type) included only case distortion and minor leaking at the seals. No serious breaching occurred. ${ }^{120}$ In short, it is unlikely that cells would be overheated to temperatures that approach the boiling points of any constituent; and if this does occur, the consequences appear to be limited to a small amount of leakage.

\footnotetext{
${ }^{113}$ Faxed memorandum from Dr. Harold Böhm, (AEG ZEBRA Battery Marketing GmbH), 10-7-98

${ }^{114}$ This occurrence is even more probable in the new cells since the $\beta$-alumina shape used in these cells is not as robust as that used in the older type. Source: Faxed memorandum from Dr. Harold Böhm, (AEG ZEBRA Battery Marketing GmbH), 10-7-98.

115 The internal positive electrode configuration would seem to make this case impossible while the cell retained sodium, unless the breach in question was actually a seal failue rather than a casing rupture.

${ }^{116}$ The TLV (Threshold Limit Value) for occupational exposure to hydrogen chloride is $5 \mathrm{ppm}$. International Chemical Safety Card 0163, World Health Organization/International Program on Chemical Safety \& the Commission of the European Communities

${ }^{117}$ Van Zyl and Dustmann (1995), p. 64.

${ }^{118}$ Wedlake et al. (1988), p. 162. This is especially true for the cells using steel components. Those using aluminum would experience a softening of the aluminum components.

119 Tilley and Holmes (1988), p. 54-4.

${ }^{120}$ Tilley and Holmes (1988), p. 54-4.
} 
The second point takes the first (i.e., the apparent resistance of cells to externally applied heat) into account, and the resistance of new battery designs to cell failure chain reactions, as mentioned in the section on seals. The context of that discussion was the overheating of cells from exposure to spilled sodium tetrachloroaluminate. This vulnerability was eliminated by reconfiguring the inside of the battery case to prevent pooling adjacent to the cells. This would seem also to apply to any sodium while or before it had combined with the oxygen in the battery case into sodium oxide.

All points taken into account, the preceding discussion suggests that rupture of cells within the battery does not necessarily have dramatic consequences. This inference appears to be borne out by the tests discussed below.

\section{Shock and Crushing/Deformation}

Beta Research and Development has tested Zebra cells for susceptibility to shock by subjecting them to a square wave vibration pattern inflicting up to $20 \mathrm{~g}$ of acceleration/deceleration. The investigators determined that horizontally oriented tubes seemed more failure prone (approximately $82 \%$ of the cells failed in this orientation) than those in the vertical orientation (of which none failed). The dualism of the results is significant since EV battery applications make use of the vertical orientation. ${ }^{121}$

Individual cell designs are also qualified in tests subjecting their casings to buckling. The resulting crushing of the $\beta$ "-alumina and subsequent exothermic reaction between the sodium and liquid electrolyte raises the temperature of the cell to $300^{\circ}-400^{\circ} \mathrm{C}$ in about 10 minutes. ${ }^{122}$ In these tests, the cell remained sealed and conducting. ${ }^{123}$ Additional testing showed that a current of 50 amps could be passed through a crushed, failed cell. ${ }^{124}$

Shock - as well as crushing and deformation-was also examined via two "drop" tests. ${ }^{125}$ The tests were specified by a committee of German automobile manufacturers, ${ }^{126}$ conducted by MIRA $^{127}$ on fully charged ZEB1 batteries. ${ }^{128}$ MIRA is an independent automotive technology center that provides research, information, and consulting, modeling, and validation services. MIRA operates a comprehensive set of high-technology facilities, and is headquartered in England with regional offices in the United States and Korea. ${ }^{129}$

${ }^{121}$ Tilley and Holmes (1988), pp. 54-5,6,7.

${ }^{122}$ Van Zyl and Dustmann (1995), p. 62; Wedlake et al. (1988), p. 161.

${ }^{123}$ Wedlake et al. (1988), p. 161.

${ }^{124}$ Wedlake et al. (1988), p. 161.

${ }^{125}$ MIRA Confidential Report No. K271877.

${ }^{126}$ Personal communication with Keith Clemo, project engineer, MIRA (11/20/98).

${ }^{127}$ MIRA is located in Warwickshire, England, telephone: (0203) 348541.

${ }^{128}$ The ZEB1 battery has the following specifications: Fully charged energy level, $27 \mathrm{kWh}$; Mass, 350

kg; Dimensions (mm) 1430 x 515 x 360; No. of cells, 354; Active reactants, $17.3 \mathrm{~kg}$ sodium, $45.7 \mathrm{~kg}$

$\mathrm{NaAlCl} 4$; Maximum operating temperature, $350^{\circ} \mathrm{C}$; Open circuit voltage, $152 \mathrm{~V}$. Source: MIRA

Confidential Report No. K271877.

${ }^{129}$ MIRA is recognized around the world as a leading independent automotive research organization, and was recently (June/98) awarded Ford Motor Company's Q1 certification. Ford requires this certification of its suppliers and other contractors. Obtaining it requires meeting a set of standards specified by Ford (including ISO 9000 and QS 9000) and is an important element of Ford's quality maintenance efforts. Sources: MIRA Press Release; Personal communication with Ron Iori (Ford Motor Company) 10/28/98. 
The first test consisted of dropping the battery from a height of 9.8 meters onto the end of a 1 meter long section of Armco $^{\mathrm{TM}}$ crash barrier so that the barrier impacted the center of the battery's side; this test was intended to simulate the effects of a side impact. The second consisted of dropping the battery from a height of 10 meters onto a rigid $150-\mathrm{mm}$ radius half-cylinder, and was intended to simulate the effects of a side impact into a pole or tree.

According to MIRA, the crash barrier test resulted in extensive "crumpling" of the case around the impact point, and penetration by the barrier into the case approximately $500 \mathrm{~mm}$ - some $97 \%$ of the battery width. Although the interior of the battery had been penetrated and a number of cells damaged, the case tended to bend over and around the intruding barrier, preventing the release of loose cells or other internal battery materials. Immediately after impact, thin white smoke could be seen emanating from the impact point. The original test report indicates that this material was thought to be sodium hydroxide, a hazardous material; however, later investigation determined that the material was, in fact, aluminum hydroxide with trace amounts of hydrogen chloride vapor, as discussed earlier. ${ }^{130}$ The concentration of the hydrogen chloride was determined to be less than 1 ppm, ${ }^{131}$ somewhat lower than the TLV (Threshold Limit Value) for occupational exposure of 5 ppm. ${ }^{132}$

The internal temperature of the battery rose considerably, although the proportions of this heat release attributable to combustion and to reaction between the battery reagents is unknown. Smoke emissions gradually declined over a 3-hour period. ${ }^{133}$

The "pole impact" test resulted in deformation of the case around the impact point, however, only the exterior wall of the case was penetrated; cells or other internal material did not escape, since the case tended to again bend over and around the pole, creating a depression around it. ${ }^{134}$ As with the crash test, thin white smoke could be seen around the battery, this time emanating from the access holes on the battery end face. The emission of smoke continued for approximately 1.5 hours after the impact. As with the previous test, the original report indicated that this material was thought to be sodium hydroxide. Although the report specified that the volume and density of the smoke would not require a person approaching the battery to be engulfed in, or to breathe it, a recommendation was made for the designers to identify any hazardous materials within it and to compare their concentrations with acceptable levels of exposure. As before, the smoke was later identified to be aluminum hydroxide with trace amounts of hydrogen chloride at a concentration of less than 1 ppm. ${ }^{135}$

A significant result of the pole impact test was the creation of a "hot spot" on the bottom face of the battery. The estimated temperature (on the external face of the battery) of this hot spot was $300^{\circ} \mathrm{C}$, sufficient to discolor the external shell of the battery case. ${ }^{136}$ This suggests that the vacuum-insulated battery enclosures lose a significant amount of their insulating capacity in the event that their vacuum is lost, and may have implications for the type of material used to fill the space between the inner and outer shells of the battery case. It also has implications for the imposition of design constraints on EVs using the batteries, as discussed in the section on

\footnotetext{
${ }^{130}$ Van Zyl and Dustmann (1995), p. 62.

${ }^{131}$ Memorandum from Jim Sudworth (Beta Research and Development, Ltd.) 9/29/98

${ }^{132}$ International Chemical Safety Card 0163, World Health Organization/International Program on Chemical Safety \& the Commission of the European Communities

${ }^{133}$ MIRA Confidential Report No. K271877.

${ }^{134}$ MIRA Confidential Report No. K271877/1.

${ }^{135}$ Memorandum from Jim Sudworth (Beta Research and Development, Ltd.) 9/29/98

${ }^{136}$ MIRA Confidential Report No. K271877/1.
} 
recommendations. Beta Research and Development Ltd., has determined that loss of vacuum degrades the thermal insulation factor of the battery case by a factor of three or four, leading to an external skin temperature of around $60^{\circ} \mathrm{C}$ (under normal circumstances). ${ }^{137}$

\section{Piercing}

Three possible levels of this event are readily apparent. They are intrusion: (1) only through the external wall of the battery case; (2) through both walls of the case but not damaging any cells; and (3) extending through the case and rupturing some cells.

The first level would be tantamount to a loss of vacuum insulation, and is covered in the section on thermal management and vacuum insulation. The second may be looked at as a much more severe case of the first, with the added hazards attending exposure to the battery's internal temperatures, and compromised containment of cell components in the event of a subsequent cell breach. This case is also discussed in the section on thermal management and vacuum insulation.

The third case consists of damage extending through both shells of the battery case; a reduction in its insulating ability; and rupture of one or more cells. It is thus qualitatively dissimilar to the lesser two cases defined in the previous two paragraphs, but essentially the same as the conditions imposed by the drop tests detailed earlier.

A combination piercing/fire extinguishing test was performed by MIRA, more to assess the hazards associated with an aqueous (and unsuitable) fire extinguishing medium than to address piercing per se. The results of this test are discussed in the section following gasoline fires.

\section{Gasoline Fire}

EVs are not expected to immediately displace gasoline-fueled internal combustion vehicles, even as they become economically viable competitors. Hence, it is possible to envision collisions involving both types of vehicles, with concomitant exposure to a gasoline fire being a distinct possibility.

As previously discussed, individually sealed Zebra cells have low vapor pressures below approximately $800^{\circ} \mathrm{C}$, and numerous tests have demonstrated their ability to survive higher temperatures with only minimal damage, and without inflicting significant hazards on surrounding cells or areas. ${ }^{138}$

Although the resistance of individual cells to heat or fire provides some indication of how they would fare in a battery exposed to fire, the effects of such an event were directly investigated by MIRA, by simulating these conditions for a ZEB $1 .{ }^{139}$ The fully charged, fully operational battery was suspended $400 \mathrm{~mm}$ above a tray containing burning gasoline, and maintained there for 30 minutes. Both wind speed and ambient temperatures were measured at the beginning of the test and found to be zero, and $20^{\circ} \mathrm{C}$, respectively. ${ }^{140}$ The battery case vacuum was also released to include the loss of its insulating effect.

\footnotetext{
${ }^{137}$ Memorandum from Jim Sudworth (Beta Research and Development, Ltd.) 9/29/98

138 Tilley and Holmes (1988), p. 54-4.

${ }^{139}$ MIRA Confidential Report No. K271921

${ }^{140}$ MIRA Confidential Report No. K271921
} 
The battery case remained intact, showing no damage, other than a very slight bulging of the flat faces. No leakage of internal materials from the cable ducts or vacuum port was noticed, and there were no signs of excessive heat buildup, short circuiting, or spontaneous reactions within the battery. Monitors indicated that the internal battery temperature declined slightly during the test, and that all the measured cell voltages remained normal. ${ }^{141}$

Although the test report indicated that this test did not specify criteria that would enable a pass/fail judgment, it noted that the battery: (1) did not increase (by releasing additional heat or venting combustibles) the hazard already presented by the gasoline fire; (2) did not explode or eject hot material, nor was there evidence of gases being ejected from the case; and (3) did not present a risk of electric shock caused by extensive deformation of the battery and exposure of otherwise protected internal electrical connections. On this last point, the report comments that under the circumstances: "... the only possible source of [electrical] danger will be the external connections to the battery ... and that the vehicle manufacturer would [be expected, via common sense] to incorporate fireproof labels to indicate the potential hazard." ${ }^{142}$ In short, the report concluded that the battery endured the test without burning, releasing reagents, or spontaneously reacting. ${ }^{143}$

\section{Exposure to Aqueous Fire Extinguishing Media}

Battery experts rank the severity of improper response (via lack of training) by emergency responders to a crash site as potentially quite high, but also likely to be addressed. ${ }^{144}$ A significant subset of this concern regards hazards resulting from the application of water or aqueous firefighting compounds to sodium batteries, given the reactivity of sodium with water.

MIRA tested the effects of applying an aqueous foam fire fighting agent on a fully charged ZEB1 by piercing it with a hydraulic ram, withdrawing the spike, and applying the contents of two "Chubb" handheld fire extinguishers-dispensing a total of $18 \mathrm{~kg}$ of aqueous foam, the entire contents of the extinguishers - at 3-minute intervals over a 30-minute duration. ${ }^{145}$ The test objective was simply to observe the effects of such an action on a charged, damaged, Zebra battery.

The test directives specified that the extinguishing media be applied "not less than 3 minutes after ignition, or 30 minutes after the penetration occurred if there was no ignition." 146 After the spike was withdrawn, some combustion was observed deep within the battery. This combustion appeared as a small amount of yellow flame and is thought to have been the reaction of sodium released from damaged cells and oxygen. Since it stopped in less than a minute, an additional 30 minutes was allowed to elapse before the extinguishers were brought to bear. The extinguisher spray was directed into the hole created by the hydraulic ram, from approximately half a meter away at an angle of approximately $45 \%$ to the damaged battery face. ${ }^{147}$

\footnotetext{
${ }^{141}$ A small amount of smoke later seen to emanate from the insulated ducting carrying the instrumentation cables was determined to result from a short circuit caused by a crossing of the thermocouple sheaths used in the test over the battery's terminals. This arrangement was unique to the test and not indicative of the battery's normal installation.

${ }^{142}$ MIRA Confidential Report No. K271921.

${ }^{143}$ MIRA Confidential Report No. K271921.

${ }^{144}$ Results of Electric Vehicle Safety Issues Survey, pp. 9-12.

${ }^{145}$ MIRA Confidential Report No. K271907.

${ }^{146}$ MIRA Confidential Report No. K271907.

${ }^{147}$ MIRA Confidential Report No. K271907.
} 
The aqueous foam from the first fire extinguisher is described as having had a very "liquid" consistency; accordingly, it was possible to fill the battery with foam, to the point of overflow, before boiling commenced. Test engineers reported that when the foam was initially applied, the temperature near the penetration area decreased for a short time. Much of the liquid-foam was ejected from the hole in the form of jets approximately $200 \mathrm{~mm}$ high. The test reports that the boiling process is thought to have been sustained by residual battery heat, rather than from a sodium-water reaction. ${ }^{148}$

The test report observes that the battery did not: (1) combust, explode, or otherwise undergo a buildup of pressure or heat so as to set fire to adjacent inflammables; (2) present a greater risk of inflicting scalds or burns on bystanders or emergency responders beyond that which would be expected in "any other situation where a fire extinguisher is used on hot material enclosed within a container;" (3) present, as a result of the application of aqueous foam, an additional risk of ingestion of materials within the battery; and (4) present evidence of risk from electrical discharge or of electric shock. On the third point, the report elaborates that any risk of ingestion from the circumstances of the test would seem to center around the initial combustion reported before the application of the fire extinguishing media. In short, the investigators concluded that "the battery does not constitute an additional hazard to persons in the vicinity, under the conditions of the test." 149

\section{Orientation Changes}

Current Zebra batteries do not include a sodium wick, reservoir, or pressurized delivery system, relying instead on capillary transport of sodium between a stainless steel sheath and the exterior of the $\beta$ "-alumina electrolyte to ensure sufficient electrolyte wetting. ${ }^{150}$ Consequently, orientation changes are not expected to affect the safe operation of individual cells. However, since significant orientation changes are not likely to occur outside the context of serious accidents, the more important question is not whether the cells would continue to function normally, but whether internal breakdown of cells would be more likely to occur. Given the breakdown mechanisms discussed in the section on internal failure, this seems unlikely.

Cell failures in an intact battery case have few, if any, EH\&S implications since safety tests have shown that even in an accident raising the internal temperature of the battery to $800^{\circ}-1,000^{\circ} \mathrm{C}$, the shell and insulation are able to protect the battery exterior from high temperature. ${ }^{151}$

\section{Other Severe Events}

\section{Immersion}

Immersion of a fully charged battery could be expected to create shock and reaction hazards, the latter either through liberation of hydrogen gas via electrolysis, or as the result of thermal shock rupturing cells, followed by a reaction between sodium and water. To observe the results of immersion, a Z5 (50\% state of charge, operating at $\left.300^{\circ} \mathrm{C}\right)$ was fully immersed in 1,600 liters of

\footnotetext{
${ }^{148}$ MIRA Confidential Report No. K271907.

${ }^{149}$ MIRA Confidential Report No. K271907.

${ }^{150}$ Personal communication with Jim Sudworth (Beta Research and Development, Ltd.) 9/01/98.

${ }^{151}$ Dustmann and Tilley (1996), p. 114.
} 
"pond" water. The results of the test were described by Dr. H. Böhm, of AEG Anglo Batteries $\mathrm{GmbH}$, as follows:

Large gas/vapour bubbles appeared; battery voltage (113V) did not change. After one minute a voltage of 70-80 Volts arose between the pole and battery case as well as between the negative pole and water. Within 15 minutes all voltages dropped to below 10 Volts and internal temperature was below $90^{\circ} \mathrm{C}$ (the melt had frozen). During the test 9 cells out of 220 had failed, the rest of the battery was operational with no change of performance. No cell had opened and the analysis of the pond water confirmed that no contamination had occurred. ${ }^{152}$

A similar test is planned with salt water, with the expectation that this medium's higher conductivity will result in a faster drop in the measured potentials. ${ }^{153}$

\section{Loss of Thermal Management System or Insulation}

Commercially available Zebra batteries, e.g., the Z11" the charge and thermal management systems. Loss or compromise of heating ability, or the insulating ability of the case via loss of vacuum, would, under normal conditions, result in the eventual "freezing" of the cells and the collapse of battery voltage. Loss or compromise of cooling ability, whether caused by or accompanied with a reduction in case insulating ability, would, especially during periods of high power demand, result in the elevation of internal temperatures.

As mentioned earlier, loss of vacuum in the battery case degrades its insulating ability by a factor of three or four, leading to an external battery case temperature of around $60^{\circ} \mathrm{C} .{ }^{154}$ Greater heat loss by the battery would require more of its stored energy to be devoted to maintaining a proper operating temperature, and hence reduce the unit-in-question's actual energy capacity. The degree of hazard imposed by the increased external casing temperature would depend primarily on EV design and battery placement, since $60^{\circ} \mathrm{C}$ is well under the kindling point of materials likely to be encountered in an EV, but might induce state changes in some materials and inflict scalds on skin in contact with the case for more than 3 seconds. ${ }^{155}$

The effects of very high temperatures on individual and groups of cells have already been discussed. In brief, although temperatures in the $800^{\circ}-1,000^{\circ} \mathrm{C}$ range would be expected to damage the battery components, the intrinsic characteristics (e.g., material, insulating ability, and dimensions) of the battery case protect the exterior from internal high temperatures. ${ }^{156}$ The effect of externally applied heat on individual cells has also been addressed. However, heat generated by the cells themselves, while operating, and in the absence of adequate cooling, is relevant to this section.

Monometallic nickel chloride Zebra cells have an operating temperature of $157^{\circ}-500^{\circ} \mathrm{C}$; however, the preferred range of the nickel-iron chloride design is $270^{\circ}-350^{\circ} \mathrm{C}^{157}$ The lower limit of the

\footnotetext{
${ }^{152}$ Faxed memorandum (Aug. 6, 1998) to Malcom Shemmans, relayed to NREL from Malcom Shemmans.

${ }^{153}$ Faxed memorandum (Aug. 6, 1998) to Malcom Shemmans, relayed to NREL from Malcom Shemmans.

${ }^{154}$ Memorandum from Jim Sudworth (Beta Research and Development, Ltd.) 9/29/98

${ }^{155}$ Exposure to $60^{\circ} \mathrm{C}$ water will produce a $2^{\text {nd }}$ degree burn (no irreversible damage) in 3 seconds, and a $3^{\text {rd }}$ degree burn in 5 seconds.

${ }^{156}$ Dustmann and Tilley (1996), p. 114.

157 Tilley and Holmes (1988), p. 54-5, Memorandum from Jim Sudworth (Beta Research and Development, Ltd.) 9-29-98
} 
preferred range results from the temperature dependence of the $\beta$ "-alumina electrolyte and the upper limit results from material problems that set in during continuous operation above it. ${ }^{158}$ However, the implication of this is that the operating range is somewhat flexible, and short-term excursions do not necessarily mean the death of the cell.

Cells produce heat when discharged; however, even when subjected to a short circuit they apparently reach a state of total discharge before overheating to a temperature approaching the boiling point of sodium, $882^{\circ} \mathrm{C}$ (the lowest boiling point of the cell constituents). ${ }^{159}$

A heating system failure resulting in the "freezing" of the cells in a Zebra battery does not constitute an event having EH\&S issues. Reducing the temperature of a Zebra cell results in an increase in internal resistance (due to the characteristics of $\beta$ "-alumina) until the freezing point of the liquid electrolyte is reached, at which point the cell stops operating. ${ }^{160}$ However, Zebra cells are quite tolerant of freezing since the liquid electrolyte, when solidified, takes on a "soft/soap/ friable" nature. ${ }^{161}$ Zebra cells actually undergo at least one thermal cycle in the course of the manufacturing process. ${ }^{162}$ Thirty-three $\mathrm{mm}$ and fifty-five $\mathrm{mm}$ cells undergoing thermal cycling tests $\left(250^{\circ} \mathrm{C} \rightarrow 50^{\circ} \mathrm{C} \rightarrow 250^{\circ} \mathrm{C}\right)$ one per day have survived more than 50 consecutive cycles without failure. ${ }^{163}$

\section{Thermal Shock (Abrupt Cooling)}

Zebra battery systems can operate in a wide ambient temperature range $\left(-40^{\circ}-+70^{\circ} \mathrm{C}\right)$ because of the characteristics of the insulated battery case and the thermal management system. ${ }^{164}$ To the extent that cells may be affected by very fast cooling, a possible effect would be seal failure, with previously described results. In the absence of seal or other failure, cells would be expected to cool down, as in the loss of the heating system. The immersion test previously described induced thermal shock on an operating battery with a loss of nine out of 220 cells, but did not indicate the nature of the cell failure mechanism. ${ }^{165}$ Since it is hard to envision thermal shock occurring to the individual cells of an active battery in the absence of exposure to water, it would be instructive to know the exact nature of the failure mechanism.

\section{Short Circuit}

Zebra batteries are designed with recessed terminals, effectively precluding the across-theterminal shorts possible with traditional lead acid battery configurations. ${ }^{166}$ However, assuming that a short circuit between the terminals did develop, or an accident or other event resulted in short circuiting of individual cells, the expected result would be a rapid discharge, accompanied by significant heat release. Short circuiting of Zebra cells usually does not lead to cell failure, and

${ }^{158}$ Tilley and Holmes (1988), p. 54-5.

${ }^{159}$ Tilley and Holmes (1988), p. 54-6, see Figure 3: High Rate Discharge Characteristics of a Beta 33 Cell ; Van Zyl and Dustmann (1995), p. 60.

${ }^{160}$ Sudworth (1995), p. 94.

${ }^{161}$ Wedlake (1988), p. 162. This is in notable contrast to the brittle nature sulfur tales on when a sodium/ sulfur cell cools to, or past, its freezing point.

${ }^{162}$ Wedlake (1988), p. 162.

${ }^{163}$ Wedlake (1988), p. 162.

${ }^{164}$ Dustmann (1998), p. 5 (of unpaginated document).

${ }^{165}$ Faxed memorandum (Aug. 6, 1998) to Malcom Shemmans (BET Services), relayed to NREL from Malcom Shemmans.

${ }^{166}$ Personal communication with Malcom Shemmans, (BET Services) 6/18/98. 
some cell designs can tolerate short circuiting for limited durations without performance degradation. ${ }^{167}$ Maximum current can be limited by the current carrying capacity of the cell terminals, however. ${ }^{168}$

Safety tests have shown that an internal electric short of the entire battery (a worst case scenario) could raise the internal temperature of the battery to $800^{\circ}-1000^{\circ} \mathrm{C}$. However, even under these circumstances, the shell and insulation are able to protect the battery exterior from high temperature. ${ }^{169}$ In such a case, as previously mentioned, the battery would be expected to remain closed and intact, but to emit aluminum hydroxide and trace amounts of hydrogen chloride in vapor form.

\section{Day-to-Day Operation}

\section{Overcharge}

Recall that for nickel cells, the normal charging reaction is:

$$
\text { Normal Charge: } \quad \mathrm{Ni}+2 \mathrm{NaCl} \quad \rightarrow \quad \mathrm{NiCl}_{2}+2 \mathrm{Na}
$$

The cell enters the overcharge phase when all its $\mathrm{NaCl}$ is consumed. Chlorination of the nickel cathode continues, but according to the following reaction:

\section{$1^{\text {st }}$ Phase of Overcharge: $\quad \mathbf{2 N a A l C l}_{4}+\mathbf{N i} \rightarrow \quad \mathbf{N i C l}_{2}+\mathbf{2} \mathbf{N a}+\mathbf{2} \mathbf{A l C l}_{3}$}

If overcharge continues past the point at which all the cathode metal (nickel) is consumed, the liquid electrolyte decomposes:

\section{$2^{\text {nd }}$ Phase of Overcharge: $\quad \mathbf{2 N a A l C l}_{\mathbf{4}} \quad \rightarrow \quad \mathbf{2 N a}+\mathbf{C l}_{\mathbf{2}}+\mathbf{2} \mathbf{A l C l}_{\mathbf{3}}$}

In practical cells, the third equation and release of $\mathrm{Cl}_{2}$ are not considered to be possibilities because there is a large excess of metal in the cathode, in the form of the current collector. ${ }^{170} \mathrm{At}$ full charge only $33 \%$ of the nickel in the cathode is actually chlorinated; thus, cells can be overcharged (by over 100\%) at moderate power rates before chlorine is liberated. ${ }^{171}$ However, the second overcharge phase is unlikely to be reached in practical cells because of the likelihood of cell failure during the first phase. $\beta$ "-alumina fracture is likely to result during this phase, before the excess nickel is depleted, since the space available in the anode is quickly exhausted by the excess sodium produced. Anode space is limited, since practical cell designs minimize volume, mass, and cost. ${ }^{172}$ The result is that cells can, by default, be designed to tolerate a certain degree of overcharge, and then to fail safely, before chlorine is released. ${ }^{173}$

\footnotetext{
${ }^{167}$ Wedlake (1988), p. 161.

168 Tilley and Holmes (1988), p. 54-4.

${ }^{169}$ Dustmann and Tilley (1995), p. 115.

${ }^{170}$ Tilley and Holmes (1988), pp. 54-8; Wedlake (1988), pp. 162,163.

${ }^{171}$ Wedlake (1988), pp. 162,163. Overcharge at high rates can result in chlorine gas liberation, however.

${ }^{172}$ Wedlake (1988), pp. 162,163.

${ }^{173}$ Scholz (1993), p. 11.
} 
The same holds true for mixed cathode ${ }^{174}$ cells, except that in these cells the $20 \%$ iron component of the cathode chlorinates (i.e., is charged) first, prior to the nickel charging phases depicted above. ${ }^{175}$

In summary, data indicate that a small amount of overcharge is acceptable in normal use; a large overcharge $(\sim 20 \%)$ caused by control malfunction is acceptable but may degrade cell performance; gross overcharge $(>50 \%)$ will result in cell failure but has not been shown to create hazardous circumstances. ${ }^{176}$

\section{Overdischarge}

The normal discharge reaction consists of dechlorination of the nickel and iron in the cathode, resepectively.

\section{Normal Discharge: $\quad \mathrm{NiCl}_{2}+2 \mathrm{Na} \rightarrow \mathrm{Ni}+2 \mathrm{NaCl}$ \\ $\mathrm{FeCl}_{2}+2 \mathrm{Na} \rightarrow \mathrm{Fe}+2 \mathrm{NaCl}$}

The cell enters the overdischarge phase when all the nickel and iron in the cathode are dechlorinated; discharge continues with the dissolution of the liquid electrolyte.

\section{Overdischarge: $\quad 3 \mathrm{Na}+\mathrm{NaAlCl}_{4} \rightarrow \quad 4 \mathrm{NaCl}+\mathrm{Al}$}

The overdischarge reaction is reversible as long as it is not permitted to extend to proceed too far. Most practical cells can tolerate a certain degree $(\sim 20 \%)$ of overdischarge and recover. ${ }^{177}$ Continued overdischarge will result in cell failure via $\beta$ "-alumina fracture. The ceramic electrolyte fails because the excess aluminum and sodium chloride produced in the cathode compartment cannot be accommodated, in terms of space, or because they maldistribute current, creating localized high flux regions on the electrolyte. ${ }^{178} \beta$ "-alumina fractures caused by overdischarge do not result in a "failure reaction," since by the time failure commences only a negligible amount of sodium is left in the cell. ${ }^{179}$

The overdischarge phase described above should not actually come to pass in Zebra batteries, since the battery management system is capable of detecting the different voltages produced during the discharge of iron, nickel, and aluminum, and terminates the discharge function before the breakdown of the melt actually transpires. ${ }^{180}$

\section{Thermal Cycling}

As previously discussed, Zebra cells are quite tolerant of thermal cycling, and actually undergo at least one thermal cycle in the course of the manufacturing process. ${ }^{181}$ Thirty-three $\mathrm{mm}$ and fifty-

\footnotetext{
${ }^{174}$ Including those doped with aluminum.

${ }^{175}$ Personal communication with Dr. Roger Tilley (AEG) 10/22/98.

176 Tilley and Holmes (1998), pp. 54-9.

${ }^{177}$ Wedlake (1988), pp. 163.

${ }^{178}$ Wedlake (1988), pp. 163.

${ }^{179}$ Tilley and Holmes (1988), pp. 54-10.

${ }^{180}$ Memorandum from Jim Sudworth (Beta Research and Development, Ltd.) 10/12/98.

${ }^{181}$ Wedlake (1988), p. 162.
} 
five mm cells undergoing thermal cycling tests $\left(250^{\circ} \mathrm{C} \rightarrow 50^{\circ} \mathrm{C} \rightarrow 250^{\circ} \mathrm{C}\right)$, one per day, have survived more than 50 consecutive cycles without failure. ${ }^{182}$

Zebra battery designs of a decade ago could maintain a minimum operating temperature range for as long as approximately 70 hours without additional heat or electrical input. ${ }^{183}$ Present-day Zebra batteries under no load can maintain acceptable operating temperatures for more than a week at room temperature, without additional electric or thermal energy input. ${ }^{184}$

\section{Ambient Temperature Extremes}

The battery is protected from ambient temperature extremes by its insulation and thermal management system, which includes heating and cooling capabilities. Current Zebra battery systems have an ambient temperature operating range of $-40^{\circ} \mathrm{C}-+70^{\circ} \mathrm{C} .^{185}$

\section{Polarity Reversal on Charge}

AEG Zebra indicates that current battery designs preclude reversing polarity upon charge since the terminals are not interchangeable; however, should mishandling or similar situation result in such an occurrence, the charging system would "push a discharge current through the battery."186 Assuming the charging system's current overload protection did not activate, discharge would occur until the battery was completely discharged or the battery voltage dropped to below $66 \%$ of the open-circuit voltage. ${ }^{187}$

\section{Dust/Moisture}

Cells are hermetically sealed, and the battery case protects the internal contents from dust and moisture. ${ }^{188}$

\section{Inadequate Maintenance}

Zebra cells are hermetically sealed. Zebra batteries are designed to be maintenance free, even if a few cells fail. ${ }^{189}$

\section{Tampering}

Certain aspects of the battery render it tamper-resistant. These include the recessed terminals, steel battery case, and freedom from maintenance. Also, the sheer mass of the units probably provides some deterrent against tampering. ${ }^{190}$

\footnotetext{
${ }^{182}$ Wedlake (1988), p. 162.

${ }^{183}$ Wedlake (1988), p. 162.

${ }^{184}$ Personal communication with Malcom Shemmans, 6/18/98.

${ }^{185}$ Dustmann (1998), p. 5 (of unpaginated document).

${ }^{186}$ Faxed memorandum (Aug. 6, 1998) to Malcom Shemmans, relayed to NREL from Malcom Shemmans.

${ }^{187}$ Faxed memorandum (Aug. 6, 1998) to Malcom Shemmans, relayed to NREL from Malcom Shemmans.

${ }^{188}$ Dustmann (1998), p. 1 (of unpaginated document).

${ }^{189}$ Dustmann and Tilley (1996), p. 115.

${ }^{190}$ Dustmann and Tilley (1996), p. 116. The Z11 weighs approximately $310 \mathrm{~kg}$ (683 lb).
} 


\section{Vibration}

Zebra cells and batteries have been subjected to a number of tests to measure their susceptibility to vibration and shock. Beta Research and Development has carried out fixed amplitude vibration and shock tests subjecting cells to sine wave vibrations at 2,4 , and $8 \mathrm{~g}$ for $10^{7}$ cycles, and extreme shock of up to $20 \mathrm{~g}$ using square waves. Tests simulating vehicle conditions were also performed, using a test regime considered to be equivalent to 100,000 miles of normal driving. ${ }^{191}$ As was the case in associated tests investigating cells' vulnerability to shock, the investigators determined that horizontally oriented tubes seemed more failure prone. Zebra cells used in EV batteries are mounted in the vertical orientation. ${ }^{192}$

Failure modes caused by vibration are the same as those associated with and previously described for shock.

\footnotetext{
191 Tilley and Holmes (1988), pp. 54-5,6,7.
}

192 Tilley and Holmes (1988), pp. 54-5,6,7. 


\section{Manufacturing, Disposal, and Shipping}

\section{Introduction}

Although they may be somewhat peripheral to the consumer-operator, the manufacturing, disposal, and shipping phases of a product's lifetime may have significant personnel and economic implications. This is particularly true for automotive technology applications, given the size and impact of this sector of the global economy. The intrinsic and operational safety characteristics of Zebra cells are not confined, in terms of relevance, to the service period of their lifetime. Many of these characteristics (e.g., safe cell failure modes, lack of cell failure shunts) also influence (reduce) the degree of hazard imposed during the other phases. Zebra technology also has characteristics whose EH\&S implications are specific to these three phases. Following is a brief discussion of these topics.

\section{Manufacturing}

Although the general intrinsic and operational safety characteristics of Zebra cells apply during manufacture as well as during operation in an EV, the fact that Zebra cells can be manufactured without using or handling metallic sodium has EH\&S implications that are distinctly relevant to manufacturing. Metallic sodium is promiscuously reactive, and requires special handling. It was thus recognized early on that the possibility offered by Zebra cells of sodium-free fabrication was a highly desirable attribute. ${ }^{193}$ This is conferred, as discussed earlier, by using a mixture of sodium chloride and metal powder in the cathode section of the cell, and the application of heat and a charge only after the cell has been hermetically sealed. It is only after this point, as charging proceeds, that free sodium begins to accumulate in the cell's negative electrode section.

Zebra cells are tested and brought up to charge in the manufacturing facility, and because of high reliability and resistance to damages inflicted by freeze/thaw cycles, can be discharged and cooled down for shipping, if necessary. ${ }^{194}$

\section{Shipping}

NREL examined the EH\&S issues of Zebra and sodium/sulfur batteries in a 1992 report: Environmental, Health, and Safety Issues of Sodium/Sulfur Batteries for Electric and Hybrid Vehicles, Volume III: Transport of Sodium/ Sulfur and Sodium/Metal-Chloride Batteries. It was possible to address both technologies in a single volume because assessment of the hazards posed in transport indicated that there was no need to draw a distinction between the two different technologies.

At the time of the NREL report, sodium-beta batteries were authorized for transport under exemption provisions, and a proposal had been submitted to "incorporate basic provisions for the large-scale commercial transport of cold (non-activated) sodium-beta batteries and cells" into the United Nations Recommendations on the Transport of Dangerous Goods. ${ }^{195}$

\footnotetext{
${ }^{193}$ Many of the early papers (mid to late 1980s) on the technology expressed enthusiasm over this prospective, even as they addressed operational issues such as capacity retention and power-rate.

192 Tilley and Holmes (1988), p. 54-10. Personnel communication with Malcom Shemmans, 6/18/98.

${ }^{195}$ Environmental, Health, and Safety Issues of Sodium-Sulfur Batteries for Electric and Hybrid Vehicles, Volume III: Transport of Sodium-Sulfur and Sodium-Metal-Chloride Batteries, p. 7.
} 
The "UN Recommendations" address the various requirements of hazardous materials transport, e.g., definitions of hazards classes, listing of hazardous materials, and packaging requirements. ${ }^{196}$ Although these recommendations have no regulatory force, they form the basis for a number of international agreements. ${ }^{197}$ Recognizing the need for U.S. exporters to comply with these agreements, the U.S. Department of Transportation (DOT) has for a number of years incorporated these international standards, and under some circumstances, allowed them to be used in lieu of DOT regulations. ${ }^{198}$ This relationship, including the implementation of parallel DOT regulations following UN decisions, results in the UN Recommendations having a direct effect on U.S. domestic and international shipping. ${ }^{199}$

Since the publication of the NREL report, the proposal on sodium beta batteries has been adopted by the UN Committee, and was published in the 1993 edition of the UN Recommendations. On the basis of this UN action, the International Maritime Organization (IMO) and the International Civil Aviation Organization (ICAO), incorporated identical provisions for the transport of sodium-beta batteries into the international sea and air transport regulations ${ }^{200}$ promulgated, respectively, by those organizations. These provisions were effective from January 1, 1995, and remain in force at the time of writing. Similar provisions were incorporated, with the same effectivity date, into the regulations governing national and international transport by road and rail within Europe ${ }^{201}$, and in certain countries adjacent to that region.

The DOT has published a final rule ${ }^{202}$ amending its regulations to incorporate the UN provisions for sodium beta batteries. This amendment became effective on October 1, 1995. However, under the final rule compliance with the new provisions was authorized beginning from January 1, 1995, in order to conform to the implementation date of the corresponding amendments to the international sea and air transport regulations. The resulting comprehensive, globally harmonized, regulatory regime governing the transport of sodium beta batteries not only facilitates the transport of these articles, but, at the same time, takes appropriate account of their size, configuration and the limited risk they pose in transport (as compared to the risks posed by their principal hazardous component, sodium).

\footnotetext{
${ }^{196}$ Environmental, Health, and Safety Issues of Sodium-Sulfur Batteries for Electric and Hybrid Vehicles, Volume III: Transport of Sodium-Sulfur and Sodium-Metal-Chloride Batteries, p. 2.

${ }^{197}$ E.g., the International Maritime Organization and the International Civil Aviation Organization.

${ }^{198}$ DOT Hazardous Materials Regulations ("the HMR"), Title 49, Code of Federal Regulations, Parts 171180. See also: Environmental, Health, and Safety Issues of Sodium-Sulfur Batteries for Electric and Hybrid Vehicles, Volume III: Transport of Sodium-Sulfur and Sodium-Metal-Chloride Batteries, p. 5.

${ }^{199}$ Environmental, Health, and Safety Issues of Sodium-Sulfur Batteries for Electric and Hybrid Vehicles, Volume III: Transport of Sodium-Sulfur and Sodium-Metal-Chloride Batteries, p. 5.

${ }^{200}$ The regulations concerned are the IMO International Maritime Dangerous Goods Code ("the IMDG Code") and the ICAO Technical Instructions for the Safe Transport of Dangerous Goods by Air ("the Technical Instructions").

201 The European Agreement Concerning the International Carriage of Dangerous Goods by Road ("the ADR") and the Regulations Concerning the Carriage of Dangerous Goods by Rail ("the RID").

${ }^{202}$ Final rule published in the Federal Register on December 29, 1994, under Docket No. HM-215A [59 FR 67390].
} 


\section{Disposal/Recycling}

Disposal methods and costs are currently being investigated, with an emphasis in Germany on developing recycling options, since German law allows disposal as hazardous waste only if reuse and recycling have been studied and demonstrated to be infeasible. ${ }^{203}$

From the perspective of disposal or recycling a Zebra battery can be viewed as having three major components:

Cells - accounting for $73 \%$ of the total mass.

Battery Case-accounting for $19 \%$ of the total mass

Remainder ${ }^{204}$-accounting for $8 \%$ of the total mass.

The cells and battery case are not considered reusable, and there is disagreement about the reusability of the remaining components. ${ }^{205}$ This leaves recycling as the next option for the cells and battery case, and possibly for some or all of the remainder.

Recycling is considered to be economically attractive because of the amount of nickel contained in the cells. It has also been demonstrated that the nickel present can be recovered in a very pure form by overdischarging the battery and so recombining the metallic sodium with chlorine into common salt. This salt and the solidified electrolyte melt (sodium tetrachloroaluminate) are then leached from the cathode compartment with water. ${ }^{206}$ The nickel is left as a fine powder of about $95 \%$ purity. Approximately $90 \%$ of the nickel in a cell may be recovered using this method. ${ }^{207}$ No EH\&S concerns beyond those already identified for these constituents in the previous section on intrinsic hazards are obvious.

Although details and costs of the recycling/disposal process are still under investigation. AEG Zebra aims to have an operational recycling process by the time batteries begin to be returned after EV service. ${ }^{208}$

\footnotetext{
${ }^{203}$ Recyclingstudie, ZEBRA Z12-Batterie, p. 6.

${ }^{204}$ E.g., the battery management system controller, cooling system, cooling system box, interface box, etc.

${ }^{205}$ Recyclingstudie, ZEBRA Z12-Batterie, p. 7.

${ }^{206}$ Sudworth (1994), p. 100.

${ }^{207}$ Sudworth (1994), p. 100.

${ }^{208}$ Sudworth (1994), p. 100.
} 


\section{Summary and Recommendations}

The Zebra system, particularly current pilot-line batteries, appears to present relatively low intrinsic risks during normal operation and from the minor mishaps that might be expected during such operation. Although this evaluation does not include, and has not been made with, a rigorous quantitative comparison with other battery technologies or other EV fuel sources, it does derive from a review of the literature (much of which is written by AEG Zebra affiliates) and testing to date, and appears to be shared by others who are knowledgeable about it and related technologies.

This report finds the following to apply to Zebra technology in general:

1. Cell failures have been shown to have non-catastrophic results.

2. Cell failure chain reactions are difficult to sustain, but if sustained might, under some conditions-and depending upon EV design—result in significant safety impacts.

3. When subjected to extreme external influences simulating vehicle accidents batteries do not appear likely to add additional significant hazards to occupants or emergency response personnel. (See recommendations.)

4. Cell failure shunts (looping elements) are unnecessary and therefore do not present additional hazards from failure.

5. Cells have a relatively wide operating temperature range.

6. Batteries can operate at a wide range of ambient temperatures because of their thermal management systems and insulated cases.

7. Cells are tolerant of freeze/thaw cycling.

8. Cell constituents have low vapor pressures at operating temperatures and most temperatures to which they are likely to be exposed.

9. When cells are exposed to high enough temperatures to compromise their containment function, the EH\&S hazards imposed from the resulting failure are apparently small. (See recommendation 2.)

10. Sources of chronic corrosion are absent.

11. Cells may be fabricated without handling or using metallic sodium.

12. Cells can be designed to fail safely when overcharged.

13. Cells fail safely when overdischarged.

14. Safe recycling of the batteries and cells appears to be possible.

15. Batteries can be safely and legally shipped in the cold state.

The Zebra system appears, from the available information, to be relatively safe with respect to severe influences of the kind normally associated with vehicle collisions or accidents. While it must be emphasized that this evaluation does not include, and has not been made with a rigorous quantitative comparison with other battery technologies, or other electric vehicle energy sources, it does derive from a review of the available information and testing up to date, and appears to be shared by others who are knowledgeable about it and related technologies. However, a more concrete appraisal could be made if certain questions, referenced in the following recommendations, were addressed.

1. Zebra developers should regularly report on the experience of the pilot program, and compile information on EH\&S incidents experienced during its course to: (1) identify any hazards that may as yet be unidentified, and provide information on how to mitigate or remove them; and (2) provide information from which to maintain up-to-date assessments of the system's safety. 
2. Zebra developers should determine the likely aluminum hydroxide and hydrogen chloride exposure pathways for occupants or emergency response personnel, as a result of cell rupture, per the recommendation of MIRA.

3. Although it seems apparent that under some circumstances, significant hot spots could develop in the battery interior, and coupled with a compromised insulating ability, might reduce the battery system's ability to prevent significant heating of corresponding portions of the battery's exterior, it is not clear what effect this would have on the rest of the EV or the safety of the occupants. These questions should be addressed and answered, perhaps with the collaboration of EV manufacturers.

4. AEG Zebra stresses that a breached cell is very unlikely to release sodium, since any trauma capable of breaching the cell will almost certainly simultaneously fracture the ceramic electrolyte, binding all available sodium into sodium chloride. ${ }^{209}$ Zebra representatives also stress that to their knowledge, free sodium has never been released in any of the tests conducted by MIRA. ${ }^{210}$ Given this background, it seems that the release of metallic sodium from Zebra cells in an operational battery is unlikely; however, the effects of such an event still remain unclear. Investigation should be undertaken to determine: (1) if there are (relevant) circumstances under which an operating Zebra cell would, in fact, release sodium, and (2) what effects sodium released from a cell or set of cells would have in an operating battery-perhaps via a simulation akin to that conducted for sodium tetrachloroaluminate.

5. The safety implications of using aqueous fire extinguishing agents on damaged Zebra batteries, although addressed in the MIRA test referenced, have not been investigated to the degree concerns about them warrant. The MIRA test is very encouraging, but seems to have been rather limited in scope since it did not make clear how many cells were actually ruptured and their contents available for reaction with water. Moreover, it is not clear that the extinguishing media should have been applied after the specified waiting periods had elapsed. It is recommended that the test be repeated, with fire extinguishing media applied while combustion was still visible, and under conditions in which the battery was more heavily damaged.

6. The failure mode of cells in batteries subjected to water immersion is not specified in the literature reviewed, although the reference to the immersion test indicates that none of the cells opened. It would be instructive to know the exact nature of this mechanism since seal failure or jacket breach could result in the exposure of water to sodium, while a ceramic electrolyte fracture would presumably result only in the failure of the cell in the conducting mode.

7. Independent testing by NREL, ANL, or another DOE laboratory of the new "mixed cathode" batteries is recommended.

This review of the available literature, and discussions with authoritative sources, did not reveal any EH\&S issues that could seriously impair the use of this technology in EVs. However, it is recommended by the author that these conclusions be further substantiated by testing at NREL, ANL, SNL, or another government laboratory or testing facility.

\footnotetext{
${ }^{209}$ See, for example, Van Zyl and Dustmann (1995), p. 62.

${ }^{210}$ Memorandum from Jim Sudworth (Beta Research and Development, Ltd.) 9/29/98; Memorandum from Dr. H. Böhm (AEG ZEBRA Battery Marketing) 10/7/98.
} 


\section{Bibliography}

Adendorff, K.T.; M.M. Thackery (May 1987). Identification and Structural Characteristics of $\mathrm{Na}_{8-2 \mathrm{x}} \mathrm{Fe}_{\mathrm{x}} \mathrm{Cl}_{8}$ Phases in High Temperature $\mathrm{Na} / \mathrm{FeCl}_{2}$ Cells, E.C.S. Philadelphia.

Barrow, P. (June 1988). Boehmite, the Raw Material for Production of Beta Alumina, Beta Battery Workshop VII, Toronto, Canada.

Bones, R.J.; J. Coetzer; R.C. Galloway; D.A. Teagle (Oct. 1986). "A Sodium/ $\mathrm{FeCl}_{2}$ Cell with a Beta Alumina Electrolyte,” E.C.S. San Diego, No. 763, J. Electrochem. Soc. 134(10):2379.

Bones, R.J.; D.A. Teagle; S.D. Brooker; F.L. Cullen; J. Lumsdon (May 1987). “An Insight into the Operation of an $\mathrm{Fe} / \mathrm{FeCl}_{2}$ Electrode in a Medium Temperature Liquid Sodium/Beta Alumina Cell," E.C.S. Philadelphia (Abs. 553), in Proc. 2nd Symp Electrode Materials \& Processes for Energy Conv \& Storage Vol. 87-12, p. 537.

Bones, R.J.; D.A. Teagle; S.D. Brooker; F.L. Cullen (Oct. 1987). Development of a Ni/Ni $\mathrm{Cl}_{2}$ Cathode for a Liquid Sodium/ $\mathrm{BAl}_{2} \mathrm{O}_{3}$ Cell, 172nd Electrochem. Soc. Meeting, Honolulu (Abs. 158).

Bones, R.J.; D.A. Teagle; .S.D. Brooker (Sept. 1988). Fabrication of Discharged Positive Electrodes for Sodium/Metal Chloride (ZEBRA) Battery Cells, 16th Internat. Power Sources Symp., Bournemouth, U.K.

Bones, R.J.; D.A. Teagle; B. Hendel; G.J. Dudley (1992). Development of $\mathrm{Na} / \mathrm{NiCl}_{2}$ (ZEBRA) Cells for Space Applications, Extended (Abs.), Fall Meeting 182nd, Electrochem. Soc. Toronto, Canada.

Bull, R.; W. Bugden (June 1988). "Reliability Testing of Zebra Cells," in Proceedings: DOE/ EPRI Beta (Sodium/ Sulfur) Battery Workshop VII, Toronto, Canada.

Cleaver, B.; V.S. Sharivker (May 1994). "Thermal Asymmetry in High Temperature Cells," in Proceedings of the Ninth International Symposium on Molten Salts of The Electrochemical Society, Inc. (Vol. 94-13), pp. 805-811.

Clemo, K.C. (1992). Drop Test on a ZEB1 Sodium Nickel Chloride Traction Battery to Simulate Vehicle Crash Conditions (Pole Impact), Conducted 2 July 1992, MIRA Project Report No K271877/1.

Clemo, K.C. (1992). Drop Test on a ZEB1 Sodium Nickel Chloride Traction Battery to Simulate Vehicle Crash Conditions (Crash-Barrier Penetration), Conducted 28 April 1992, MIRA Project Report No K271877.

Clemo, K.C. (1992). Petrol Fire Test on Beta Research ZEB1 Sodium Nickel Chloride Battery (30 Minute Burn), Conducted 20 August 1992, MIRA Project Report No K271921.

Clemo, K.C. (1992). "Fire Extinguishing on a Damaged Battery," ...on a Beta ZEB1 Sodium Nickel Chloride Battery, MIRA Project Report No K271907. 
Coetzer, J. (1986). “A New High-Density Battery System,” J. Power Sources 18:377-380.

Coetzer, J. (Oct. 1986). Chlorinated Metal Carbides as Positive Electrode Materials, E.C.S. San Diego (Abs. 762).

Coetzer, J. (Sept. 1987). Sodium/Iron Chloride Secondary Cells: An Interpretation of the Reaction Mechanism, "Solid State Ionics" Conference, Garmisch, Germany.

Coetzer, J. (Oct. 1987). An Electric Vehicle Range Test using a Sodium/Iron Chloride Battery in a Converted Minibus, 172nd Electrochem. Soc. Meeting, Honolulu (Abs. 155).

Dell, R.M.; R.J. Bones (Aug. 1987). The Sodium/Metal Chloride Battery, 22nd IECEC Philadelphia, paper 879326.

Dell, R.M.; R.J. Bones (Feb. 1988). High Temperature Sodium Batteries-A Comparative Review, Internat. Symp. on Batteries and Fuel Cells, Karaikudi, India.

Dudley, G.J.; B. Hendel; R.J. Bones (Aug. 1991). "Evaluation of Sodium Nickel Chloride Cells for Space Applications," in Proceedings of the European Space Power Conference held in Florence, Italy, 2-6 September 1991 (ESA SP-320), pp. 423-429.

Dustmann, C.-H.; R. Tilley (1996). "Power Improved ZEBRA Battery for Zero Emission Vehicles," in Strategies in Electric and Hybrid Vehicle Design. Warrendale, PA: Society of Automotive Engineers, Inc., pp. 113-119.

Dustmann, C.-H. (Mar. 1998). "Latest Advancement on the Zebra Battery," presented at the March 4-5, 1998 Meeting of the ad hoc Advanced Battery Readiness Working Group, Washington, D.C., Published at the EVS-14 Conference in December 1997 in Orlando, FL.

Foust, O.J. (ed.) (1978). "Sodium Systems, Safety, Handling, and Instrumentation" in SodiumNaK Engineering Handbook, Vol. III. New York: Gordon and Breach, Science Publishers, Inc.

Galloway, R.C. (Jan. 1987). “A Sodium/Beta Alumina/Nickel Chloride Secondary Cell,” J. Electrochem. Soc. 134:256.

Galloway, R.C. (Oct. 1987). A 100 Ah Sodium/Nickel Chloride Cell for Electric Vehicle Applications, 172nd Electrochem. Soc. Meeting, Honolulu (Abs. 159).

Galloway, R.C. (June 1988). Track and Bench Testing of the Sodium/Nickel Chloride Zebra Battery, Beta Battery Workshop VII, Toronto, Canada.

Kamaludeen, M.; N.G. Renganathan; M. Raju; P.L. Sankar; A. Visuvasam (June 1992). "Sodium Metal Chloride Battery-An Overview," Bulletin of Electrochemistry 8(6).

Moseley, P.T.; R.J. Bones; et.al (May 1992). "Stability of $\beta_{\mathrm{Al}_{2} \mathrm{O}_{3} \text { in Sodium/FeCl}}$ (ZEBRA) Cells," J. Electrochem. Soc. 136:5.

Nicholson, N.D.; D.S. Demott; R. Hutchings (Sept. 1988). Characterization of the Positive Electrode in Sodium/Metal Chloride (ZEBRA) Cells, 16th Internat. Power Sources Symp., Bournemouth, U.K. 
Prakash, J.; L. Redey, P.A. Nelson; D.R. Vissers (July 1996). "High-Temperature Sodium Nickel Chloride Battery for Electric Vehicles," to be published in the Proceedings of the 190th Meeting of The Electrochemical Society; October 6-11, 1996. (ANL/CMT/CP-90780 CONF-961040--8). Argonne, IL: Argonne National Laboratory.

Redey et al. (1994). Electrochemical Cell, U.S. Patent 5,283,135.

Redey, L.; J. Prakash; D.R. Vissers (Feb. 1994). "Sodium Nickel-Chloride Battery Development," Submitted for publication in the Post-Conference Proceedings of the 1993 Annual Automotive Technology Development Contractors' Coordination Meeting (CONF-9310169--3), pp. 1-4.

Scholz, H. (Dec. 1993). "The Zebra Battery: A New High Energy Concept for Vehicle Applications," Power International, pp. 10-11.

Sudoh, M.; J. Newman (Mar. 1990). Modeling of the Sodium/ $/ \mathrm{FeCl}_{2}$ Battery.

Sudworth, J.L.; R.C. Galloway; D.S. Demott (Oct. 1987). Sodium/Metal Chloride Cells for High Power Applications, 172nd Electrochem. Soc. Meeting, Honolulu (Abs. 782).

Sudworth, J.L. (June 1988). Life and Reliability Data on the $\mathrm{AAl}_{2} \mathrm{O}_{3}$ Produced from Boehmite, Beta Battery Workshop VII, Toronto, Canada.

Sudworth, J.L. (June 1988). High Power Sodium/Nickel Chloride Cell, Beta Battery Workshop VII, Toronto, Canada.

Sudworth, J.L. (Feb. 1988). Sodium Metal Chloride Batteries with Beta Alumina Electrolyte, Chemistry \& Industry.

Sudworth, J.L. (1994). "The Sodium/Nickel Chloride (Zebra ${ }^{\mathrm{TM}}$ ) Battery," in Electrochemistry and Clean Energy. Cambridge, UK: Royal Society of Chemistry; pp. 95-100.

Tilley, A.R.; R.N. Bull (Aug. 1987). The Design and Performance of Various Types of Sodium/ Metal Chloride Batteries, IECEC Philadelphia.

Tilley, A.R.; W.A.Holmes (June 1988). "Environmental Testing of Zebra Cells," in Proceedings: DOE/EPRI Beta (Sodium/Sulfur) Battery Workshop VII, Toronto, Canada.

Vissers, D.R.; I.D. Bloom; M.C. Hash; L. Redey; C.L. Hammer; D.W. Dees; P.A. Nelson (June 1988). "Development of High Performance Sodium/Metal Chloride Cells," in Proceedings: DOE/ EPRI Beta (Sodium/ Sulfur) Battery Workshop VII, Toronto, Canada.

Wedlake, R.J.; D.A. Teagle; A.R. Tilley (Feb. 1988). Safety Studies on Sodium/Beta Alumina/ $\mathrm{NaAlCl}_{3} / \mathrm{MCl}_{2}$ Cells, Internat. Symp. on Batteries and Fuel Cells, Karaikudi, India.

Wedlake, R.; J. Coetzer; I. Vlok (Feb. 1989). "The Performance Characteristics of Over Discharged Sodium/Metal Chloride (Zebra) Cells," Electric Vehicle Developments 8(1):27.

Wright, M.L.; J.L. Sudworth; P. Barrow (Oct. 1987). Sodium/Iron Chloride Cells, 172nd Electrochem. Soc. Meeting, Honolulu (Abs. 103). 
Van Zyl, A.v.; C.-H Dustmann (Nov. 1995). "Safety Aspects of Zebra High Energy Batteries," in Conference Proceedings, WEVA Conference for Electric Vehicle Rearch, Development and Operation, November 13, 14, 15, 1995; Paris. Bruxelles, Belgium. pp. 57-63. 


\title{
Appendix \\ Toxicities and Reactivities of Chemical Elements and Compounds Potentially Associated with Sodium/Metal Chloride Batteries
}

\begin{abstract}
Aluminum
Aluminum is not considered to be particularly hazardous, either in safety or toxicological terms. Aluminum dusts are considered to be nuisance particulates, with few adverse effects on respiratory tissues when exposures are kept under reasonable control. Powdered aluminum is stable under ordinary conditions of use and storage. However, it is moderately flammable, and can produce hydrogen when exposed to water. Aluminum is not considered to be carcinogenic. ${ }^{211}$

\section{Aluminum Chloride}

Aluminum chloride is a white crystalline odorless powder. It is completely water soluble, not inflammable, and not considered to be an explosion hazard. Fires extinguishing media include water, $\mathrm{CO}_{2}$, or dry chemicals. It may cause irritation to the respiratory tract, the symptoms including coughing and shortness of breath. It has a low single dose ingestion toxicity, but ingestion of large amounts may cause nausea, vomiting, and abdominal spasms. Skin contact may result in irritation. It may emit chlorine fumes when heated to decomposition. It is not known or anticipated to be a carcinogen. ${ }^{212}$
\end{abstract}

\section{$\underline{\text { Aluminum Oxide }}$}

Aluminum oxide $\left(\mathrm{Al}_{2} \mathrm{O}_{3}\right)$ is a white powder that may irritate eyes and upper respiratory tract. Its dust may easily reach concentrations that are harmful upon inhalation or contact, if it is not properly contained. Safe handling requires containment within ventilation hoods or breathing protection and eye protection. Aluminum oxide is not combustible, and any type of fire extinguisher may be used for fires where it is present. ${ }^{213}$

\section{Chlorine}

Chlorine, under standard temperature and pressure, is a strong-smelling greenish-yellow gaseous element, and is denser than air. It is a strong eye and respiratory irritant, with potentially lethal corrosive effects on these tissues in concentrations above the occupational exposure limit. Chronic exposure may cause chronic bronchitis and tooth decay. If chlorine is released from a container, it readily forms concentrations in the vicinity that are harmful upon inhalation. Protective clothing, including gloves and safety goggles, as well as breathing protection or a closed ventilation system to contain the gas, are needed for safe handling. Chlorine is violently reactive with ammonia, organic compounds, and metal dusts, and poses significant fire and explosion hazards. Metal, plastic, rubber, and coatings may be corroded by chlorine, or by the hydrochloric

${ }^{211}$ Material Safety Data Sheet, Alcan Aluminum Corporation.

${ }^{212}$ Material Safety Data Sheet, Mallinckrodt Baker, Inc.

${ }^{213}$ International Chemical Safety Cards 
acid formed when it reacts with water. Because of this reaction, water should not be used directly in chlorine spills, which complicates the mitigation of chlorine-associated fire hazards. ${ }^{214}$

$\underline{\text { Iron }}$

Iron metal in commonly encountered forms does not present EH\&S hazards. The hazardousness of iron is heavily dependent upon its physical form. As an ultra-fine powder (ca. 5 microns) it is pyrophoric and can ignite spontaneously in air. As dust suspended in the air it presents a moderate fire hazard when exposed to heat or flame; the minimum ignition temperature of an iron dust cloud is $430^{\circ} \mathrm{C}$. Iron dust can also react with water, liberating flammable hydrogen gas. Thus, water should not be used as a fire extinguishing agent, nor should $\mathrm{CO}_{2}$ or dry chemical extinguishing agents be used. MSDS sheets recommend instead powdered graphite, powdered salt, or powdered limestone.

Iron may cause irritation to the respiratory tract, and when ingested in extremely large doses, may cause gastrointestinal disturbances (vomiting, abdominal pain, etc.) and lethargy and shock. In extreme cases toxicity may progress, developing into an increase in blood acidity, blood discoloration, fever, liver damage, and possibly death.

Skin exposure does not result in adverse effects; however, eye exposure can result in redness and pain, and deposition of iron particles can leave a "rust ring" or brownish stain on the cornea.

\section{Ferrous Chloride}

Ferrous chloride $\left(\mathrm{FeCl}_{2}\right)$ is a greenish-white-yellow deliquescent crystalline substance with appreciable solubility in water. It should be kept away from fire and other ignition sources, as well as sodium and potassium. If exposed to potassium or sodium, it may undergo exothermic polymerization, resulting in a violent explosion. ${ }^{215}$ Its thermal decomposition products may include toxic and corrosive chlorine fumes. Fire extinguishing media appropriate for this material are: dry chemicals, $\mathrm{CO}_{2}$, halon, water spray, foam, and fog. ${ }^{216}$

Dermal exposure to ferrous chloride may result in irritation, burns, dermatitis, and poisoning through absorption. Inhalation may cause difficult breathing and irritation of the mucous membranes. Ingestion may cause a range of effects, including gastrointestinal disorders, leukocytosis, cyanosis, cardiovascular collapse, liver/kidney/pancreatic damage, and possible death. ${ }^{217}$

Ferrous chloride is not considered to be a carcinogen. ${ }^{218}$

\section{Iron (ii) Sulfide}

Iron sulfide is an iron salt that may cause skin, digestive tract, and respiratory tract irritation, although its toxicological properties have not been investigated. It is incompatible with strong acids and may decompose in their presence to create oxides of sulfur and/or hydrogen sulfide. ${ }^{219}$

\footnotetext{
${ }^{214}$ International Chemical Safety Cards)

${ }^{215}$ Material Safety Data Sheet, Occupational Health Services, Inc.

${ }^{216}$ Material Safety Data Sheet, Fisher Scientific, Chemical Division

${ }^{217}$ Material Safety Data Sheet, Occupational Health Services, Inc.

${ }^{218}$ Material Safety Data Sheet, Fisher Scientific, Chemical Division

${ }^{219}$ Material Safety Data Sheet, Acros Organics
} 


\section{Nickel and Nickel Chloride}

Nickel is a metallic element. There is considered to be limited evidence for the carcinogenicity of nickel and certain nickel compounds in humans, with an actual cancer hazard being associated with the early stage of nickel refining. ${ }^{220}$ In addition to carcinogenicity, respiratory and eye irritation, and dermatitis are other health hazards of nickel and nickel chloride. ${ }^{221}$ Exposure may occur through inhalation, ingestion, or skin contact. Protective clothing, eye or face protection, and proper ventilation are needed for safe handling. Nickel and many of its compounds undergo violent reactions with certain reactants. For example, violent reactions occur with fluorine, ammonium nitrate, hydrazine, ammonia, hydrogen and dioxane, performic acid, phosphorus, selenium, sulfur, and titanium and potassium chlorate. ${ }^{222}$ Nickel will react with mineral acids to produce potentially explosive hydrogen gas, and will react violently with strong oxidizers in general. Fine nickel powder or dust is highly combustible. ${ }^{223}$ Nickel chloride is stable under normal use and storage, though it can react to form hazardous products, such as oxides of nickel and chlorine, chlorine, or chloride. When exposed to air, it uneventfully absorbs water until it forms a solution.

\section{$\underline{\text { Sodium }}$}

Sodium is an alkali metal. It is severely corrosive to the respiratory or digestive tract or skin upon inhalation, ingestion, or skin contact. Chronic exposure may cause dermatitis, mucous membrane irritation, and lung damage. Safe handling requires a ventilation system, personal respirators, impervious clothing, and eye or face protection. Sodium reacts violently with water and oxygen, and virtually anything else that is capable of being reduced. ${ }^{224}$ Flammable or explosive hydrogen may form upon contact with water or atmospheric moisture.

\section{$\underline{\text { Sodium Beta Alumina }}$}

Beta alumina is a white powder or ceramic oxide of sodium, lithium, and aluminum with the chemical composition of $\mathrm{Na}_{1.7} \mathrm{Li}_{0.3} \mathrm{Al}_{10.7} \mathrm{O}_{17}$. In high concentrations, its dust may cause physical irritation to the eyes and respiratory tract. It may aggravate bronchitis, emphysema, and asthma. It is not known to be toxic, carcinogenic, mutagenic, teratogenic, or to irritate the skin. Protective clothing, including gloves, face protection, aprons, sleeves, and boots; dust respirators, and extraction hoods are used to mitigate the risks of handling this material. Upon exposure to air, it absorbs $\mathrm{CO}_{2}$ and water without significant heat evolution. ${ }^{225}$

\section{$\underline{\text { Sodium Chloride }}$}

Sodium chloride $(\mathrm{NaCl})$ is a primary constituent of table salt. It is a minor skin and eye irritant, and may cause stomach irritation if large quantities are ingested.

${ }^{220}$ Report on Carcinogens, $8^{\text {th }}$ Edition, "Nickel and Certain Nickel Compounds"

${ }^{221}$ Material Safety Data Sheet, Mallinckrodt Baker, Inc.

${ }^{222}$ Report on Carcinogens, $8^{\text {th }}$ Edition, "Nickel and Certain Nickel Compounds"

${ }^{223}$ Material Safety Data Sheet, Mallinckrodt Baker, Inc.

${ }^{224}$ Material Safety Data Sheet, Mallinckrodt Baker, Inc.

${ }^{225}$ Ionotec Limited, 


\section{Sodium Fluoride}

Sodium fluoride is a white, odorless, moderately water-soluble powder. It does not present unusual fire or explosive hazards and fires in which it is involved can be extinguished with agents appropriate for the other materials around it. It should not be exposed to acids and has highly toxic and corrosive decomposition products. Inhalation or ingestion may be harmful or fatal. Contact or inhalation can cause skin, eye, and mucous membrane irritation, or fluorosis. Control of dust is essential, and material should be stored away from fire hazards and acids, in a cool dry place with plenty of ventilation. ${ }^{226}$

${ }^{226}$ Material Safety Data Sheet, Orlex Chemical 


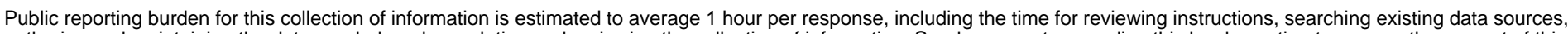

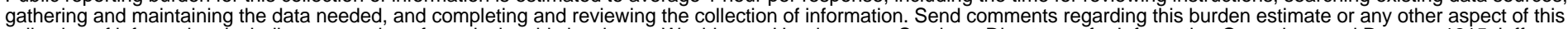

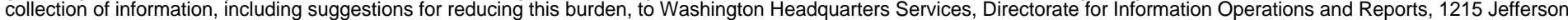
Davis Highway, Suite 1204, Arlington, VA 22202-4302, and to the Office of Management and Budget, Paperwork Reduction Project (0704-0188), Washington, DC 20503.

\begin{tabular}{|l|l|l|l}
\hline 1. AGENCY USE ONLY (Leave blank) & $\begin{array}{c}\text { 2. REPORT DATE } \\
\text { November } 1998\end{array}$ & $\begin{array}{l}\text { 3. REPORT TYPE AND DATES COVERED } \\
\text { Technical Report }\end{array}$ \\
\hline
\end{tabular}

4. TITLE AND SUBTITLE

5. FUNDING NUMBERS

Current Status of Health and Safety Issues of Sodium/Metal Chloride (Zebra) Batteries WW171000
6. AUTHOR(S)
D. Trickett

7. PERFORMING ORGANIZATION NAME(S) AND ADDRESS(ES)

8. PERFORMING ORGANIZATION REPORT NUMBER

National Renewable Energy Laboratory

1617 Cole Boulevard

Golden, CO 80401-3393

9. SPONSORING/MONITORING AGENCY NAME(S) AND ADDRESS(ES)

National Renewable Energy Laboratory

1617 Cole Boulevard

Golden, CO 80401-3393

10. SPONSORING/MONITORING AGENCY REPORT NUMBER

NREL/TP-570-25553

\section{SUPPLEMENTARY NOTES}

12a. DISTRIBUTION/AVAILABILITY STATEMENT

12b. DISTRIBUTION CODE

National Technical Information Service

U.S. Department of Commerce

5285 Port Royal Road

Springfield, VA 22161

13. ABSTRACT (Maximum 200 words) This report addresses environmental, health, and safety issues associated with sodium/metal chloride batteries in general, with specific references to unit, developed or being developed by AEG Zebra Marketing.

\section{SUBJECT TERMS}

electric vehicle, sodium/metal chloride, electrolyte, electrode, battery

15. NUMBER OF PAGES

52

16. PRICE CODE

\begin{tabular}{l|l}
\hline $\begin{array}{l}\text { 17. SECURITY CLASSIFICATION } \\
\text { OF REPORT }\end{array}$ & $\begin{array}{l}\text { 18. SECURITY CLASSIFICATION } \\
\text { OF THIS PAGE }\end{array}$
\end{tabular}

19. SECURITY CLASSIFICATION OF ABSTRACT
20. LIMITATION OF ABSTRACT

Standard Form 298 (Rev. 2-89) Prescribed by ANSI Std. Z39-18 